\title{
Review of the association between retinal microvascular characteristics and eye disease
}

\author{
Alexander Newman MD, 1,2 Nicholas Andrew MBBS ${ }^{3}$ and Robert Casson DPhil
}

FRANZCO 3

${ }^{1}$ Gold Coast University Hospital, Queensland, Australia. Department of
Ophthalmology, Level 1, Gold Coast University Hospital, Southport, Queensland

4215, Australia.

${ }^{2}$ Griffith University School of Medicine, Griffith University, Southport, Queensland 4215, Australia.

${ }^{3}$ South Australian Institute of Ophthalmology, and the University of Adelaide, South Australia

Correspondence: Dr Alexander Newman, Department of Ophthalmology, Level 1, Gold Coast University Hospital, Southport, Queensland 4215, Australia

Email: ar.newman@hotmail.com

Short running title: Review of retinal microvascular changes in eye disease Received 11 April 2017; accepted 22 November 2017

Conflict of interest: None

Funding sources: None

\begin{abstract}
Computerized retinal imaging technologies enable the static and dynamic measurement of a range of retinal microvascular parameters. Large populationbased studies have reported associations between these microvascular indices and various ophthalmic diseases including diabetes, age-related macular degeneration, retinal artery embolism, retinal vein occlusion, glaucoma, and non-glaucomatous optic neuropathies. Increasingly sophisticated imaging and analysis techniques have
\end{abstract}

This article has been accepted for publication and undergone full peer review but has not been through the copyediting, typesetting, pagination and proofreading process, which may lead to differences between this version and the Version of Record. Please cite this article as doi: 10.1111/ceo.13119 
the potential to provide relevant clinical information regarding disease risk and progression; however, further studies are required to verify associations and strengthen the predictive power of these techniques. We summarise the current state of knowledge regarding retinal microvascular characteristics and eye disease.

Keywords: Retinal vessel diameter, Arteriole, Retinal-imaging, Venule, Vascular disease

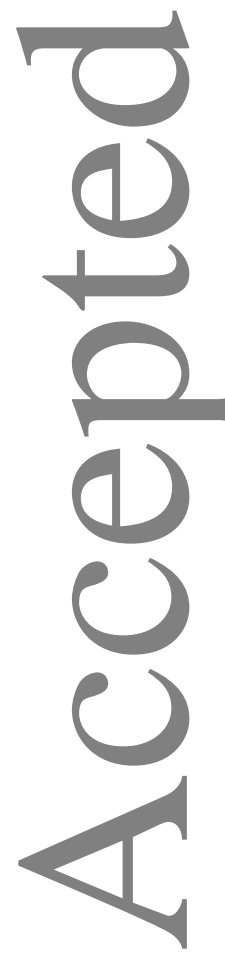




\section{NTRODUCTI ON}

The retina receives dual blood supply from both the retinal and the choroidal circulations ${ }^{1}$. After exiting the optic nerve, the central retinal artery branches into four main intra-retinal arterioles which form an end-arterial system with the exception of small anastamoses with the pial vascular plexus surrounding the optic disc $^{2-4}$. The arterioles are connected to venules by anastamostic capillaries which are arranged into inter-connected vascular plexi within the outer retinal layers ${ }^{1,3,4}$. The retinal circulation does not penetrate beyond the outer plexiform layer, necessitating the delivery of nutrients to the photoreceptors via the choriocapillaris 2,3 .

Several authors have described an anatomical and physiological homology shared between the retinal, myocardial, and cerebral microvasculature ${ }^{5-9}$. These shared characteristics naturally prompted research into the utility of retinal microvascular assessment as a prognostic tool. In recent times, computerised imaging technologies made it feasible to characterise the retinal microvasculature in vivo at a population level. Population-based studies utilising these image analysis techniques have explored associations between retinal microvascular abnormalities and a multitude of systemic and ophthalmic diseases. Important findings include the association between retinal arteriolar narrowing and systemic hypertension, and conversely the risk of developing hypertension in subjects with narrowed arterioles ${ }^{10}$. Retinal microvascular changes have also been shown to predict an individual's risk of cerebrovascular and cardiovascular events, in addition to established cardiovascular risk factors ${ }^{10-21}$. However, these same retinal microvascular changes are also observed in a proportion of the healthy adult population emphasising our need to better understand how these retinal vascular clues stratify an individual's risk of disease ${ }^{22}$.

The relationships between ophthalmic diseases and established cardiovascular risk factors have been assessed in large population-based studies. However, it remains difficult to conclusively determine the association of each risk factor for a specific ophthalmic pathology, as different study populations have shown variability in risk 
factor profiles. It is therefore difficult to accurately estimate a given patient's risk of ophthalmic disease based on their cardiovascular risk factors. The independent associations of retinal microvascular characteristics with ophthalmic diseases have recently been explored in population-based studies, as they have been with systemic diseases. In this review, we summarise the retinal microvascular changes which show independent associations with ophthalmic diseases. These microvascular changes may one day help to inform an individual's risk of ophthalmic disease and bolster the predictive capacity of established cardiovascular risk factors, which have not always demonstrated consistent relationships across populations.

\section{RETI NAL I MAGI NG METHODS}

Retinal microvascular calibre is one of the most commonly reported biomarkers and has excellent measurement reproducibility, with inter- and intra-grader coefficients of up to 0.99 when using semi-automated computerised technology ${ }^{23}$. In contrast, structural vessel alterations such as focal arteriolar narrowing and arteriovenous nicking as assessed by trained observers using retinal photography demonstrate lower inter-grader reproducibility of between $0.40-0.79^{6}$. In the region between half and one disc diameter from the optic disc margin (termed Zone B), the retinal vessels are arteriolar and venular rather than arterial or venous. Semi-automated technologies have been developed to take multiple vessel measurements within this region which are then combined to produce 'retinal vascular indices' using formulae such as the revised Knudston-Parr-Hubbard formula (Figure 1) 24,25. The central retinal arteriolar and venular equivalents, CRAE and CRVE respectively, are indices representing the average calibre of the respective vessels.

Figure 1: Retinal fundus photograph illustrating quantitative microvascular assessment of vessel diameter in Zone B by semi-automated computer software (IVAN; Department of Ophthalmology Visual Science, University of Wisconsin, Madison, WI, USA). The respective diameter measurements are combined to produce the microvascular indices CRAE and CRVE. Reproduced from I kram et.al. with permission ${ }^{26}$. 
Semi-automated methods can also be used to measure geometric indices of the retinal vasculature. The branching pattern of the normal vascular bed conforms to an ideal configuration that optimises blood distribution and blood flow whilst minimising endothelial shear stress ${ }^{27,28}$. Retinal geometric indices measure the departure of the retinal vessel arrangement from an ideal configuration (termed optimality deviance $)^{23,27}$. Geometric indices are thought to better represent the health of the microvascular bed than calibre indices; ${ }^{29,30}$ however, good data is lacking on their predictive capacity compared to calibre measurements and structural alterations such as focal arteriolar narrowing ${ }^{31}$. Characteristics of a vessel's geometry that can be measured include tortuosity, bifurcation angle, length-to-diameter ratio, and optimality deviance. These each provide some information regarding the health of the vascular network ${ }^{31,32}$. The retinal vasculature of healthy controls branches in a similar and repeating pattern each time it divides, a trait termed 'self-similarity'. The fractal dimension of the vascular bed is a mathematical index that encapsulates the overall geometric complexity of the vascular network, determining how efficiently the branching pattern fills a two-dimensional space (Figure 2) ${ }^{28,32,33}$. As with vascular calibre, retinal vessel fractal dimension has shown significant associations with cardiovascular diseases including, hypertension, stroke, and ischaemic heart disease mortality28.

Figure 2: a) Computerised quantitative assessment of retinal vessel fractal dimension (SIVA, Singapore Institute Vessel Assessment-Fractal version 1.0, School of Computing, National University of Singapore, Singapore). The complexity of branching determines how well the repeating branching pattern fills a twodimensional space. b) An example of low fractal dimension compared with c) a high fractal dimension. Reproduced from I kram et.al. with permission ${ }^{26}$.

Dynamic measures of retinal microvascular characteristics in response to provocation have also featured in the recent literature, particularly in the study of diabetes and retinal vein occlusion. Dynamic measures such as the change in vessel calibre in response to diffuse luminance flicker provide evidence of endothelial dysfunction and 
altered neurovascular autoregulation, and serve as an adjunct to information obtained from static microvascular measures ${ }^{27}$. The ability of dynamic measures to predict risk of disease compared with static retinal analysis is yet to be determined ${ }^{34}$.

\section{PATHOPHYSI OLOGY OF MI CROVASCULAR MALADAPTATI ON}

Changes are hypothesised to occur within the retinal microvasculature in response to the cumulative insult from multiple local, systemic, and genetic pathological processes ${ }^{35}$. Furthermore, the damaging effects of each exposure appear to cause structural changes specific to either the arteriolar or venular systems within the retinal vasculature. Structural alterations in the arteriolar circulation have been described to occur in four non-sequential phases as a result of arteriosclerosis, increased vasomotor tone, and remodelling of the vessel wall tunics in response to systemic hypertension $22,35,36$. The hypertensive retinopathy is initially characterised by generalised arteriolar narrowing as a result of local autoregulatory mechanisms in response to elevated intraluminal pressure. Subsequent prolonged exposure to elevated blood pressure precipitates chronic arteriosclerotic remodelling within the vessel walls which is appreciated clinically as focal arteriolar narrowing, arteriovenous nicking, and arteriolar wall opacification. Additional phases are appreciated clinically as retinal haemorrhages, hard exudates, cotton wool spots, and retinal ischaemia as a result of insult to the blood-retinal barrier.

The autoregulation of retinal blood flow is achieved by a complex dynamic between myogenic, metabolic, vasoactive hormone, light-induced, and endothelial mechanisms ${ }^{37-39}$. However dysfunction of nitric oxide-dependent endothelium driven vasodilation has been implicated in the narrowing of retinal arteriolar calibre 35,40 . Homeostatic dysregulation of nitric oxide, the most potent endothelium-derived vasodilator, may lead to a predominance of vasoconstrictive influences, also exacerbated by co-morbid atherosclerotic and vasospasm which impair NO signalling through oxidative stress damage ${ }^{39}$. The mechanisms surrounding maladaptation of the venous retinal microcirculation have more consistently shown associations with markers of systemic inflammation in population-based studies ${ }^{41-43}$. The widened 
venular diameter is thought to be due to potentiated nitric oxide synthase activity induced by inflammatory cytokines ${ }^{44}$. In addition to these cross-sectional observations, retinal venular dilatation has demonstrated associations with conditions with systemic inflammation such as obesity ${ }^{45-47}$ and the metabolic syndrome ${ }^{48,49}$, as well as in response to provocation testing ${ }^{50,51}$.

\section{AGE RELATED MACULAR DEGENERATION}

Age-related macular degeneration (AMD) shares many histological, inflammatory and biochemical similarities with the lipid deposition, connective tissue degeneration and reduced vascular compliance seen in atherosclerosis. These similarities underpin a hypothesised vascular model of disease describing the pathogenesis of $\mathrm{AMD}^{52,53}$. Epidemiological studies suggest that AMD, particularly advanced disease, shares significant associations with cardiovascular disease including carotid atherosclerotic plaques, peripheral vascular disease, hypertension, diabetes, obesity, ischaemic heart disease, and smoking ${ }^{54-64}$. These associations however have remained inconsistent and remain unable to be universally demonstrated $60,62,65-71$. Despite the incongruence in the reported systemic associations, large epidemiological studies have typically suggested a modest association between AMD and tobacco smoking ${ }^{70-}$ 74.

Prospective and cross-sectional data from population studies have shown inconsistent trends in retinal microvascular calibre and retinopathy and the incidence or prevalence of AMD respectively (Table 1 ). The data from multiple cross-sectional population-based studies has revealed no association between focal or generalised retinal vascular calibre changes or arteriovenous (AV) nicking and AMD prevalence ${ }^{75-}$ 77. The Singapore Malay Eye Study showed that increased venular calibre was associated with early AMD with no associations found for arteriolar diameter ${ }^{78}$ whereas the Handan Eye Study found arteriolar dilation rather than venular diameter to correlate with early macular disease ${ }^{79}$. Prospective population data across multiple continents indicates that 
retinal vessel diameters do not demonstrate a statistically significant correlation with the incidence of $A M D^{72,77,80-82}$.

Long term data from the Blue Mountains (BMES) and Beaver Dam Eye Studies (BDES) did however identify a weak association between both arteriolar narrowing and venular dilatation and incident retinal pigment epithelium (RPE) depigmentation ${ }^{77,80}$. J eganathan and colleagues identified a prevalent association between narrow arteriolar and larger venular calibre and RPE pigment disturbance ${ }^{78}$ and investigators from the Handan Eye Study also reported an association between arteriolar dilation and soft distinct drusen ${ }^{79}$. 


\begin{tabular}{|c|c|c|c|c|c|c|c|c|c|}
\hline & & & & \multicolumn{6}{|c|}{ Reported Associations With Retinal Microvascular Indices } \\
\hline Study & Design & Population & Characteristic & $\begin{array}{l}\text { Narrowed } \\
\text { Arteriolar } \\
\text { Calibre }\end{array}$ & $\begin{array}{l}\text { Widened } \\
\text { Venular } \\
\text { Calibre }\end{array}$ & $\begin{array}{l}\text { Focal } \\
\text { Arteriolar } \\
\text { Narrowing }\end{array}$ & $\begin{array}{l}\text { Arteriovenous } \\
\text { Nicking }\end{array}$ & $\begin{array}{l}\text { Vessel Wall } \\
\text { Opacification }\end{array}$ & $\begin{array}{l}\text { Fractal } \\
\text { Dimension }\end{array}$ \\
\hline $\begin{array}{l}\text { Chin } 2014^{75} \\
\text { Indian } \\
\text { Singaporean }\end{array}$ & $\begin{array}{l}\text { Population- } \\
\text { based } \\
\text { Cross- } \\
\text { sectional }\end{array}$ & $\begin{array}{l}\mathrm{n}=3112 \\
\text { Response }= \\
75.6 \% \\
\text { Age }=>40\end{array}$ & Early AMD & $\begin{array}{l}p=0.32 \\
\text { OR } 0.94 \\
(0.84-1.34)\end{array}$ & $\begin{array}{l}p=0.63 \\
\text { OR } 0.96 \\
(0.76- \\
1.21) \\
\end{array}$ & - & - & - & - \\
\hline $\begin{array}{l}\text { Xu } 2006^{76} \\
\text { Chinese }\end{array}$ & $\begin{array}{l}\text { Population- } \\
\text { based } \\
\text { Cross- } \\
\text { sectional } \\
\end{array}$ & $\begin{array}{l}\mathrm{n}=4439 \\
\text { Response = } \\
83.4 \% \\
\text { Age }=>40\end{array}$ & $\begin{array}{l}\text { Early AMD } \\
\text { Late AMD } \\
\text { Early \& Late } \\
\text { AMD }\end{array}$ & $\begin{array}{l}p=0.30 \\
p=0.19 \\
p=0.60\end{array}$ & $\begin{array}{l}- \\
- \\
-\end{array}$ & $\begin{array}{l}p>0.78 \\
p>0.38 \\
p>0.63\end{array}$ & $\begin{array}{l}p>0.72 \\
p>0.99 \\
p>0.37\end{array}$ & $\begin{array}{l}- \\
- \\
-\end{array}$ & $\begin{array}{l}- \\
- \\
-\end{array}$ \\
\hline $\begin{array}{l}\text { Klein } 2004^{77} \\
\text { American }\end{array}$ & $\begin{array}{l}\text { Population- } \\
\text { based } \\
\text { Cross- } \\
\text { sectional }\end{array}$ & $\begin{array}{l}\mathrm{n}=4926 \\
\text { Response = } \\
83.1 \% \\
\text { Age }=43-84\end{array}$ & $\begin{array}{l}\text { Early AMD } \\
\text { Late AMD } \\
\text { Neovascular } \\
\text { AMD } \\
\uparrow R P E \\
\text { Pigmentation } \\
\downarrow \text { RPE } \\
\text { Pigmentation } \\
\end{array}$ & $\begin{array}{l}p=0.37 \\
p=0.60 \\
p=0.97 \\
p=0.18 \\
p=0.62\end{array}$ & $\begin{array}{l}- \\
- \\
- \\
- \\
-\end{array}$ & $\begin{array}{l}p=0.20 \\
p<0.001 \\
p<0.001 \\
p=0.002 \\
p=0.01\end{array}$ & $\begin{array}{l}p=0.67 \\
p=0.18 \\
p=0.03 \\
p=0.61 \\
p=0.51\end{array}$ & $\begin{array}{l}- \\
- \\
- \\
- \\
-\end{array}$ & $\begin{array}{l}- \\
- \\
- \\
- \\
-\end{array}$ \\
\hline $\begin{array}{l}\text { Klein } 2004^{77} \\
\text { American }\end{array}$ & $\begin{array}{l}\text { Population- } \\
\text { based } \\
\text { Longitudinal } \\
10 \text { year } \\
\text { Incidence }\end{array}$ & $\begin{array}{l}\mathrm{n}=2764 \\
\text { Response }= \\
83.1 \% \\
\text { Age }=43-84\end{array}$ & $\begin{array}{l}\text { Early AMD } \\
\text { Late AMD } \\
\text { Neovascular } \\
\text { AMD } \\
\uparrow R P E \\
\text { Pigmentation } \\
\downarrow R P E \\
\text { Pigmentation }\end{array}$ & $\begin{array}{l}p=0.63 \\
p=0.28 \\
p=0.69 \\
p=0.91 \\
p=0.02\end{array}$ & $\begin{array}{l}- \\
- \\
- \\
- \\
-\end{array}$ & $\begin{array}{l}p=0.37 \\
p=0.77 \\
p=0.28 \\
p=0.21 \\
p=0.39\end{array}$ & $\begin{array}{r}p=0.04 \\
- \\
- \\
p=0.49 \\
p=0.17\end{array}$ & $\begin{array}{l}- \\
- \\
- \\
- \\
-\end{array}$ & $\begin{array}{l}- \\
- \\
- \\
- \\
-\end{array}$ \\
\hline $\begin{array}{l}\text { Jeganathan } \\
2008^{78} \\
\text { Malay } \\
\text { Singaporean }\end{array}$ & $\begin{array}{l}\text { Population- } \\
\text { based } \\
\text { Cross- } \\
\text { sectional }\end{array}$ & $\begin{array}{l}\mathrm{n}=3265 \\
\text { Response }= \\
78.7 \% \\
\text { Age }=40-80\end{array}$ & $\begin{array}{l}\text { Early AMD } \\
\text { Late AMD } \\
\text { Neovascular } \\
\text { AMD } \\
\uparrow R P E \\
\text { Pigmentation } \\
\downarrow R P E\end{array}$ & $\begin{array}{l}\text { OR } 1.15 \\
(0.84-1.34) \\
\text { OR } 0.79 \\
(0.22-2.85) \\
\text { OR } 1.16 \\
(0.15-8.81) \\
\text { OR } 1.35\end{array}$ & $\begin{array}{l}\text { OR } 1.52 \\
(1.11- \\
2.09) \\
\text { OR } 0.71 \\
(0.23- \\
2.19) \\
\text { OR 1.23 }\end{array}$ & $\begin{array}{l}- \\
- \\
- \\
- \\
-\end{array}$ & $\begin{array}{l}- \\
- \\
- \\
- \\
-\end{array}$ & $\begin{array}{l}- \\
- \\
- \\
- \\
-\end{array}$ & $\begin{array}{l}- \\
- \\
- \\
- \\
-\end{array}$ \\
\hline
\end{tabular}




\begin{tabular}{|c|c|c|c|c|c|c|c|c|c|}
\hline & & & Pigmentation & $\begin{array}{l}(1.09-1.68) \\
\text { OR } 1.08 \\
(0.90-1.31)\end{array}$ & $\begin{array}{l}(0.22- \\
6.93) \\
\text { OR } 1.19 \\
(0.97- \\
1.46) \\
\text { OR } 1.17 \\
(0.98- \\
1.41)\end{array}$ & & & & \\
\hline $\begin{array}{l}\text { Yang } 2012^{79} \\
\text { Chinese }\end{array}$ & $\begin{array}{l}\text { Population- } \\
\text { based } \\
\text { Cross- } \\
\text { sectional }\end{array}$ & $\begin{array}{l}\mathrm{n}=6648 \\
\text { Response }= \\
90.4 \% \\
\text { Age }=>30\end{array}$ & $\begin{array}{l}\text { Early AMD } \\
\uparrow R P E \\
\text { Pigmentation } \\
\downarrow \text { RPE } \\
\text { Pigmentation }\end{array}$ & $\begin{array}{l}p=0.02 \dagger \\
p=0.15 \dagger \\
p=0.84 \dagger\end{array}$ & $\begin{array}{l}p=0.14 \\
p=0.87 \\
p=0.85\end{array}$ & $\begin{array}{l}- \\
- \\
-\end{array}$ & $\begin{array}{l}- \\
- \\
-\end{array}$ & $\begin{array}{l}- \\
- \\
-\end{array}$ & 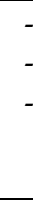 \\
\hline $\begin{array}{l}\text { Wang } 2004^{72} \\
\text { Australian }\end{array}$ & $\begin{array}{l}\text { Population- } \\
\text { based } \\
\text { Longitudinal } \\
5 \text { year } \\
\text { incidence }\end{array}$ & $\begin{array}{l}\mathrm{n}=2335 \\
\text { Response }= \\
82.4 \% \\
\text { Age }=>49\end{array}$ & $\begin{array}{l}\text { Early AMD } \\
\text { Late AMD } \\
\text { Neovascular } \\
\text { AMD } \\
\text { RPE } \\
\text { Abnormality }\end{array}$ & $\begin{array}{l}\text { Non- } \\
\text { significant } \\
\text { Non- } \\
\text { significant } \\
\quad- \\
\quad-\end{array}$ & $\begin{array}{l}- \\
- \\
-\end{array}$ & $\begin{array}{l}\text { OR } 1.3(0.8- \\
2.1) \\
\text { OR } 2.1(0.9- \\
4.9) \\
\text { OR } 2.0(0.7- \\
6.0) \\
\text { OR } 1.1(0.6- \\
2.0)\end{array}$ & $\begin{array}{l}\text { OR } 1.8(1.1- \\
2.9) \ddagger \\
\text { OR } 2.2(0.9- \\
5.7) \neq \\
\text { OR } 1.9(0.6- \\
6.2) \ddagger \\
\text { OR } 1.2(0.7- \\
2.0) \ddagger\end{array}$ & $\begin{array}{l}- \\
- \\
- \\
-\end{array}$ & $\begin{array}{l}- \\
- \\
- \\
-\end{array}$ \\
\hline $\begin{array}{l}\text { Liew } 2006^{80} \\
\text { Australian }\end{array}$ & $\begin{array}{l}\text { Population- } \\
\text { based } \\
\text { Longitudinal } \\
10 \text { year } \\
\text { incidence }\end{array}$ & $\begin{array}{l}\mathrm{n}=1952 \\
\text { Response }= \\
82.4 \% \\
\text { Age }=>49\end{array}$ & $\begin{array}{l}\text { Early AMD } \\
\text { Late AMD } \\
\text { Neovascular } \\
\text { AMD } \\
\text { RPE } \\
\text { Abnormality }\end{array}$ & $\begin{array}{l}\text { RR } 1.0(0.9- \\
1.2) \\
\text { RR } 1.2 \\
(0.9-1.7) \\
\text { RR } 1.2 \\
(0.8-1.9) \\
\text { RR } 1.1 \\
(1.0-1.3)\end{array}$ & $\begin{array}{l}\text { RR } 1.1 \\
(0.9-1.2) \\
\text { RR } 1.1 \\
(0.8-1.5) \\
\text { RR } 1.1 \\
(0.7-1.6) \\
\text { RR } 1.1 \\
(1.0-1.3)\end{array}$ & $\begin{array}{l}\text { OR } 1.2(0.7- \\
1.9) \\
\text { OR } 2.2(1.1- \\
4.1) \\
\text { OR } 2.0(0.9- \\
4.5) \\
\text { OR } 1.1(0.7- \\
1.8)\end{array}$ & $\begin{array}{l}\text { OR } 1.5(1.0- \\
2.3) \neq \\
\text { OR } 2.6(1.2- \\
5.5) \neq \\
\text { OR } 3.3(1.4- \\
7.8) \neq \\
\text { OR } 1.2(0.8- \\
1.8) \neq\end{array}$ & $\begin{array}{l}- \\
- \\
- \\
-\end{array}$ & - \\
\hline $\begin{array}{l}1 \mathrm{kram} 2005^{81} \\
\text { Netherlands }\end{array}$ & $\begin{array}{l}\text { Population- } \\
\text { based } \\
\text { Longitudinal } \\
5.2 \text { year } \\
\text { incidence }\end{array}$ & $\begin{array}{l}\mathrm{n}=6418 \\
\text { Response }= \\
78 \% \\
\text { Age }=>55\end{array}$ & $\begin{array}{l}\text { Early AMD } \\
\text { All AMD } \\
\text { AMD } \\
\text { progression } \\
\text { AMD lesions }\end{array}$ & $\begin{array}{l}\text { OR 1.08 } \\
(0.96-1.20) \\
\text { OR 1.03 } \\
(0.93-1.15) \\
\text { Non- } \\
\text { significant } \\
\text { Non- } \\
\text { significant }\end{array}$ & $\begin{array}{l}\text { OR 1.02 } \\
(0.91- \\
1.14) \\
\text { OR 1.04 } \\
(0.93- \\
1.16) \\
\text { Non- } \\
\text { significant }\end{array}$ & $\begin{array}{l}- \\
- \\
- \\
-\end{array}$ & $\begin{array}{l}- \\
- \\
- \\
-\end{array}$ & $\begin{array}{l}- \\
- \\
-\end{array}$ & . \\
\hline
\end{tabular}




\begin{tabular}{|c|c|c|c|c|c|c|c|c|c|}
\hline & & & & & $\begin{array}{l}\text { Non- } \\
\text { significant }\end{array}$ & & & & \\
\hline $\begin{array}{l}\text { You } 2012^{82} \\
\text { Chinese }\end{array}$ & $\begin{array}{l}\text { Population- } \\
\text { based } \\
\text { Longitudinal } \\
5 \text { year } \\
\text { incidence }\end{array}$ & $\begin{array}{l}\mathrm{n}=3251 \\
\text { Response = } \\
83.4 \% \\
\text { Age }=>40\end{array}$ & Early AMD & $p=0.84$ & $p>0.20$ & $p=0.20$ & $p=0.18$ & - & - \\
\hline $\begin{array}{l}\text { Klein } 1999^{83} \\
\text { American }\end{array}$ & $\begin{array}{l}\text { Population- } \\
\text { based } \\
\text { Cross- } \\
\text { sectional }\end{array}$ & $\begin{array}{l}\mathrm{n}=11532 \\
\text { Response = } \\
>46 \% \\
\text { Age }=43-84\end{array}$ & $\begin{array}{l}\downarrow R P E \\
\text { Pigmentation }\end{array}$ & - & - & $\begin{array}{l}\text { OR } 1.79 \\
(1.07-2.98)\end{array}$ & - & - & - \\
\hline
\end{tabular}

Table 1: Summary of the prevalent and incident associations between age-related macular degeneration and retinal microvascular maladaptations.

OR $=$ Odds Ratio with 95\% confidence interval. RR = Relative Risk with 95\% confidence interval. AMD = age-related macular degeneration. $\mathrm{RPE}=$ retinal pigment epithelium.

†Associations reported for wider arteriolar calibre rather than narrower calibre.

$\ddagger$ Associations reported for moderate/severe rather than mild arteriovenous nicking. 
Structural microvascular changes including AV nicking, and focal arterial narrowing which itself may represent a more marked alteration in microvascular structure than generalised arteriolar narrowing, have been recognised as independent risk factors for incident macular disease and RPE atrophy $72,77,80,83$. However other investigators have been unable identify a significant association between these microvascular alterations and prevalent ${ }^{76}$ or incident $\mathrm{AMD}^{82}$.

The lack of associations between retinal microvascular alterations and incident or prevalent AMD has been attributed to a possible susceptibility of the choroidal rather than retinal vasculature to succumb hypertensive damage. This susceptibility is proposed to be due to differences in blood flow, oxygen tension, autoregulatory mechanisms and vessel structure between the two circulations ${ }^{72,81,84}$. According to a hypothesised vascular model of disease, this choroidal damage manifests due to lipid accumulation in the sclera and Bruch's membrane in a process similar to systemic atherosclerosis. Lipid accumulation within these tunics causes a reduction in their compliance leading to increased hydrostatic pressure and reduced blood flow within the choriocapillaris. The subsequent augmentation of choroidal permeability results in lipid deposition in Bruch's membrane with associated RPE dysfunction, structural insult to Bruch's membrane, and up-regulation of vascular endothelial growth factor (VEGF) creating a milieu enabling the development of $A M D^{53,60,77,78,83}$. It remains uncertain the degree to which the observed retinal microvascular changes are implicated in this model given the tenuous association between these changes and $\mathrm{AMD}^{76}$.

The changes in retinal vessel diameter following treatment of neovascular AMD have also been assessed in clinic-based cohorts. The treatment of eyes with neovascular AMD with intravitreal anti-VEGF agents has shown short and long-term trends towards arteriolar and possibly venular narrowing. This is thought to be due to local direct inhibition of nitric oxide synthesis ${ }^{85-88}$. An alternative explanation is that these vascular calibre changes represent a normalisation towards their baseline diameter due to mitigation of VEGF induced vasodilation, arresting of the disease process, and recovery of retinal function ${ }^{86,88}$. Although a consistent association between retinal 
vessel diameter and prevalent late AMD has not been demonstrated in populationbased studies, Micieli and colleagues found that those with neovascular AMD had wider arterioles than those with dry disease prior to treatment in a small cohort ${ }^{87}$. Within the cohort of those treated with intravitreal anti-VEGF, the eyes which were more treatment naive underwent greater vasoconstriction compared with those which had more treatments prior to enrolment in the study. These findings are speculated to implicate the involvement of other local autoregulatory and myogenic mechanisms in the maintenance of retinal blood flow ${ }^{87}$. However there was no correlation between the reduction in arteriolar dilatation and improvement in visual acuity ${ }^{87}$.

In eyes with neovascular AMD the assessment of the retinal microvasculature may still have a role in the prediction of treatment response to anti-VEGF agents. Wickremasinghe and colleagues found that wider venular calibre predicted worse visual outcome in eyes with neovascular AMD treated with intravitreal ranibizumab, possibly implicating venular calibre as a surrogate marker of disease severity ${ }^{89}$.

\section{GLAUCOMATOUS AND NON-GLAUCOMATOUS OPTI C NEUROPATHI ES}

Evidence supporting the relationship between primary open angle glaucoma (POAG) and cardiovascular risk factors has been reported to include age, hypertension, nocturnal hypotension, body mass index, diabetes, smoking, ischaemic heart disease, and stroke. These findings have contributed to the body of evidence supporting a vascular theory of glaucoma whereby glaucomatous optic neuropathy is precipitated by reduced ocular blood flow ${ }^{90-107}$. Multiple investigators however have not been able to corroborate these associations, finding no link with traditional cardiovascular risk factors ${ }^{108-111}$.

The association between focal ${ }^{112-122}$ and generalised ${ }^{91-93,123}$ arteriolar narrowing and open angle glaucoma has been demonstrated in multiple studies (Table 2); however other investigators have not found a relationship between these microvascular characteristics and glaucoma ${ }^{77,99}$. A greater degree of generalised 
arteriolar narrowing has also been associated with the severity of optic nerve damage and glaucomatous neuropathy progression113,114,117,120. Although Lam and colleagues did not find that the degree of arteriolar narrowing correlated with severity of field loss, they found that the presence of peripapillary focal arteriolar narrowing was significantly associated with a more severe visual field defect ${ }^{121}$. The associations between venular calibre and POAG have been less frequently reported than arteriolar narrowing. The published results have been mixed as some authors have identified narrowed venular calibre to be associated with prevalent glaucoma ${ }^{91,92,114}$ whilst other investigators have not been able to corroborate these findings for prevalent ${ }^{112,115}$ or incident ${ }^{99}$ glaucoma.

Data from the Blue Mountains Eye study supports that there is a generalised narrowing of vascular calibre in glaucomatous eyes ${ }^{91}$. Findings from this study also showed a significant reduction in vascular calibre of only glaucomatous eyes compared with ocular hypertensives or normals. These findings have contributed to the body of evidence that the observed vascular changes are associated with optic neuropathy rather than intra-ocular pressure (IOP) ${ }^{91,92,116}$. The absence of an association between vessel diameter and IOP has also been demonstrated in the paediatric population ${ }^{124}$. Zheng and colleagues found that narrower arterioles and venules correlate with a thinner retinal nerve fibre layer (RNFL) in glaucomatous and non-glaucomatous eyes after adjustment for IOP, lending further support to the association between vascular calibre and neuropathy independent of IOP93,125,126.

The study of participants with normal-tension glaucoma (NTG) has produced conflicting results. Two population-based studies determined that there was no statistically significant difference in arteriolar calibre between NTG and POAG subgroups ${ }^{91,92}$. Other investigators have shown that NTG is independently associated with arteriolar narrowing ${ }^{127}$ however another study revealed no relationship of NTG with vascular calibre ${ }^{128}$.

Though these microvascular alterations have been acknowledged widely in the literature, it remains uncertain whether arteriolar narrowing, focal or generalised, is 
implicated in the pathogenesis of glaucoma or is resultant from the optic neuropathy91,115,116. The results of the population based studies listed above are supported by retinal perfusion studies ${ }^{91,99,129}$ in support of a possible causality of reduced vascular diameter in the pathogenesis of glaucoma as arteriolar narrowing has been associated with glaucomatous neuropathy $91,92,113,116,122,128$. In contrast, prospective data from the Rotterdam Study revealed no relationship between arteriolar or venular diameters and incident open angle glaucoma thereby not supporting the role of retinal microvascular alterations in the pathogenesis of open angle glaucoma ${ }^{99}$. A further reason to suspect that microvascular maladaptation is not causative of POAG is that arteriolar narrowing has been shown to be non-specific for glaucoma and is instead associated with the presence of optic neuropathy. 
Table 2: Summary of population-based prevalent and incident associations between open angle glaucoma and retinal microvascular maladaptations.

IN = Inferonasal. IT = Inferotemporal. OHT = Ocular hypertension. POAG = Primary open angle glaucoma. PACG = Primary angle closure glaucoma. NTG $=$ Normal tension glaucoma.

$\mathrm{RNFL}=$ retinal nerve fibre layer thickness. IOP $=$ Intraocular pressure.

† Associations reported for wider venular calibre rather than narrower calibre. 
In the study of non-glaucomatous optic neuropathy, Jonas et. al. found focal arterial narrowing was a non-specific indicator of optic neuropathy and not pathognomonic for glaucoma ${ }^{130}$, a finding demonstrated by many investigators ${ }^{119,122,131,132}$. Jonas and colleagues favoured the idea that the reduced vessel diameter was a secondary event due to altered autoregulation of blood flow in the context of diminished ganglion cell population $118,119,130$. Non-arteritic anterior ischaemic optic neuropathy (NAAION) is another such optic neuropathy which has demonstrated association with retinal microvascular changes. NAAION has an incompletely defined atherosclerotic risk factor profile, and the mechanism by which these factors contribute to posterior ciliary circulatory insufficiency remains unclear ${ }^{133-139}$. The microvascular assessment of eyes with NAAION demonstrates arteriolar narrowing as with other forms of optic atrophy ${ }^{119,122,131}$ despite its tenuous associations with traditional and non-traditional vascular risk factors. The study of both adult 140 and paediatric ${ }^{141,142}$ populations show that smaller optic discs have narrower retinal microvasculature, indicating a possible pathological mechanism of NAAION whereby a crowding effect at the lamina cribosa leads to compression of the vasculature, predisposing to the condition ${ }^{142}$. These findings are important in understanding the pathogenesis of NAAION due to the relationship of NAAION with the congenitally small 'disc at risk'.

Two distinct methodologies have been employed in the measurement of vascular calibre in the study of optic neuropathy. The first process involves manual measurement of vessel diameter in the proximal peripapillary zone usually utilising a transparency projection or digitised image and was typically adopted in earlier clinicbased studies. This methodology is a departure from the semi-automated computerised processes utilised in the recent population-based cohort studies ${ }^{77,91-}$ 93,112 though the results from both methods have typically complemented one another. The semi-automated methods utilising the Parr-Hubbard formula and more recent iterations, average the width of multiple arterioles or venules within a defined area providing a single value to describe the calibre of the retinal microvasculature ${ }^{24}$. The phenomenon of proximal vasoconstriction has been described in studies which used manual calibre measurements to describe focal arteriolar narrowing within the 
peripapillary region ${ }^{112-119,122}$. Proximal narrowing has been treated as distinct entity compared with generalised narrowing and is hypothesised to relate to proximal microvascular vasoconstrictive influences, local changes in vessel wall structure, and peripapillary disease ${ }^{116,120-123}$. Proximal narrowing appears to be more prevalent in NAAION than glaucoma ${ }^{116,120-123}$ however this remains controversial119. Therefore measurements of vessel diameter in the peripapillary zone as used in some early studies of glaucomatous neuropathy may not be directly comparable to the newer vascular calibre measurements as these separate measures may possibly implicate distinct pathophysiological processes ${ }^{121,123}$. However studies which investigated both proximal focal and generalised arteriolar vasoconstriction have found agreement between the measures and their correlation with the presence of optic neuropathy $117,118,121,122$. Focal arteriolar narrowing as has been traditionally assessed by population-based studies of the retinal microvasculature, as opposed to proximal vasoconstriction, has been evaluated by Klein and colleagues in addition to AV nicking, however both measures did not demonstrate an association with prevalent glaucoma ${ }^{77}$.

The possible confounding effects of topical ocular hypotensive medications on the retinal microvasculature was examined by Mitchell and colleagues ${ }^{91}$. They found that the association between arteriolar narrowing and POAG was similar whether or not the subject was receiving treatment. Analysis of the Beaver Dam Eye Study cohort showed that topical ocular hypotensives, particularly beta-blockers and prostaglandin analogues were associated with narrowed arterioles and venules even though this population did not show link between glaucoma and narrowed vascular calibre $^{77,143,144}$. In clinic-based studies, consistent effects of glaucoma therapy on vessel width have not been demonstrated. This is possibly attributed to confounding by significant differences in design and methodology across studies. Some authors have shown no effect of selective or non-selective beta-blockers on vessel diameter in healthy subjects ${ }^{145-150}$, and ocular hypertensives ${ }^{151,152}$. In contrast, arteriolar narrowing has been demonstrated in healthy eyes when topical beta-blockers are used $^{153}$. Other investigators have found evidence of arteriolar dilation with betablocker use in persons with POAG and ocular hypertensives ${ }^{154,155}$. Latanoprost has 
not been found to effect retinal vessel diameter in normal ${ }^{156}$ or glaucomatous eyes $^{157}$, however has been found to induce arteriolar constriction in subjects with type 1 diabetes ${ }^{156}$. Another study by Kóthy and colleagues was unable to demonstrate any effect of commercially available ocular anti-hypertensives on the retinal vasculature of normal or glaucomatous subjects over three months ${ }^{158}$. The vascular effects of ocular hypotensive medications could potentially hinder the correct estimation of the effect of glaucomatous neuropathy on retinal vascular calibre, although these medication effects remain incompletely understood ${ }^{91}$.

\section{RETI NAL VENULAR OCCLUSI ON}

Retinal vein occlusion (RVO) is the second most common retinal vascular disorder, following diabetic retinopathy, and has a complex and incompletely defined pathogenesis. Atherosclerosis has been implicated in the RVO model of disease due in part to similar risk factor profile and associations with macrovascular disease. There is a predilection for branch RVO to affect the supertemporal quadrant with the artery positioned anteriorly to the vein in the majority of cases potentially implicating arteriosclerotic mechanical compression of the vein with subsequent venous endoluminal thrombogenesis due to laminar flow disruption and endothelial damage $e^{159-165}$.

The literature supports the relationship of age and hypertension to RVO most consistently 160,166-168 however has also implicated other traditional and nontraditional risk factors including diabetes mellitus, body fatness indices, smoking, dyslipidaemia, thrombophilia, and prevalence of cardiovascular and cerebrovascular disease states ${ }^{16,159-161,164-166,169-182}$. There also appear to be different risk factor profiles between the various phenotypes of vein occlusion ${ }^{183}$. The relationship of RVO with atherosclerotic vasculopathy remains unclear as several studies demonstrate association with atherosclerosis in other vascular beds ${ }^{164,166,173,184,185}$, whilst other studies have found no association ${ }^{159,161,165}$. It is possible that the nonsignificant findings represent bias as those without cardiovascular risk would have had improved survival and therefore have better follow-up attendance ${ }^{159,166}$. 
Independent associations of vein occlusion with cardiovascular and stroke mortality have been found especially in the younger demographic ${ }^{168,186}$. Pooled data from the BMES and BDES cohorts reveal a hazard of 2.5 times greater risk of cardiovascular death in those aged 43-69 years and a non-significant two fold risk of cerebrovascular death in males ${ }^{168}$. Klein et al. ${ }^{161}$ along with others ${ }^{187-189}$ have found vein occlusion not to be an independent risk factor for mortality therefore further studies are required to elucidate these relationships ${ }^{190}$. It remains to be seen whether modifiable risk reduction strategies are able to improve the vision or systemic prognosis of those with RVO ${ }^{178}$.

Incident branch and central RVO has shown significant associations with focal arterial narrowing but not generalised arteriolar or venular calibre ${ }^{159-161,165,166}$ (Table 3). Other chronic hypertensive and arteriosclerotic alterations including arteriovenous nicking ${ }^{160,165,166}$ and arteriolar wall opacification ${ }^{160}$ have also been associated with incident and prevalent RVO ${ }^{161}$. Investigators for the Beaver Dam Eye Study showed that focal arteriolar narrowing was associated with both incident and prevalent branch RVO, with AV nicking also showing associations with prevalent RVO ${ }^{161}$. Cugati and colleagues evaluated the ten year incidence of branch RVO finding that focal arteriolar narrowing, AV nicking, and arteriolar wall opacification were reliable predictors of incident RVO following multivariate analysis ${ }^{160}$. In this population, generalised arteriolar or venous calibre were not predictors of incident central or branch RVO ${ }^{160}$. Klein and colleagues ratified these results, finding that focal arteriolar narrowing was significantly associated with incident RVO, and that generalised vascular calibre had no relationship with incident RVO along with AV nicking ${ }^{159}$.

In addition to the relationship with incident RVO, retinal vessel wall signs including AV nicking and focal arteriolar narrowing have shown an association with prevalent RVO ${ }^{165}$. Data from two pooled population studies supports the association between these microvascular features and prevalent RVO, especially AV nicking ${ }^{166}$. Fewer studies have assessed the relationship between prevalent vein occlusion and 
generalised vessel calibre. Results of the Singapore Malay Eye Study revealed no relationship between CRAE or CRVE and prevalent RVO ${ }^{184}$. In contrast, narrower CRAE and CRVE correlated with prevalent branch RVO in a South Korean hospitalbased cohort, the authors also demonstrating that the difference in vascular calibre between old and recent venous occlusion did not achieve statistical significance ${ }^{167}$.

Dynamic assessment of the microvasculature in RVO with macular oedema has been performed using diffuse luminance flicker stimulation which increases retinal blood flow by augmenting neurovascular autoregulation of vascular diameter, producing a vasodilated hyperaemic response. This measure subsequently provides a marker of vascular endothelial function and neurovascular coupling ${ }^{34,191}$. In a cohort of patients with macular oedema, Corvi and colleagues found impaired arteriolar and venular dilation in those with RVO similar to what is reported for diabetic patients, indicating an impaired functional response of the retina as a result of ischaemia ${ }^{191}$. 


\begin{tabular}{|c|c|c|c|c|c|c|c|c|c|}
\hline & & & & \multicolumn{6}{|c|}{ Reported Associations With Retinal Microvascular Indices } \\
\hline Study & Design & Population & Characteristic & $\begin{array}{l}\text { Narrowed } \\
\text { Arteriolar } \\
\text { Calibre }\end{array}$ & $\begin{array}{l}\text { Widened } \\
\text { Venular } \\
\text { Calibre }\end{array}$ & $\begin{array}{l}\text { Focal } \\
\text { Arteriolar } \\
\text { Narrowing }\end{array}$ & $\begin{array}{l}\text { Arteriovenous } \\
\text { Nicking }\end{array}$ & $\begin{array}{l}\text { Vessel Wall } \\
\text { Opacification }\end{array}$ & $\begin{array}{l}\text { Fractal } \\
\text { Dimension }\end{array}$ \\
\hline $\begin{array}{l}\text { Klein } 2008^{159} \\
\text { American }\end{array}$ & $\begin{array}{l}\text { Population- } \\
\text { based } \\
\text { Longitudinal } \\
15 \text { year } \\
\text { Incidence }\end{array}$ & $\begin{array}{l}\mathrm{n}=2119- \\
4926 \\
\text { Response = } \\
83.1 \% \\
\text { Age }=43-84\end{array}$ & $\begin{array}{l}\text { BRVO } \\
\text { CRVO } \\
\text { BRVO and } \\
\text { CRVO }\end{array}$ & $\begin{array}{l}\text { Non- } \\
\text { significant } \\
\text { Non- } \\
\text { significant } \\
\text { Non- } \\
\text { significant }\end{array}$ & $\begin{array}{l}\text { Non- } \\
\text { significant } \\
\text { Non- } \\
\text { significant } \\
\text { Non- } \\
\text { significant }\end{array}$ & $\begin{array}{l}\text { OR } 2.74 \\
(1.40-5.35) \\
\text { OR } 0.51 \\
(0.06-4.19) \\
\text { OR } 2.08 \\
(1.05-4.12)\end{array}$ & $\begin{array}{l}\text { Non-significant } \\
\text { Non-significant } \\
\text { Non-significant }\end{array}$ & $\begin{array}{l}- \\
- \\
-\end{array}$ & $\begin{array}{l}- \\
- \\
-\end{array}$ \\
\hline $\begin{array}{l}\text { Cugati } \\
2006^{160} \\
\text { Australian }\end{array}$ & $\begin{array}{l}\text { Population- } \\
\text { based } \\
\text { Longitudinal } \\
15 \text { year } \\
\text { Incidence } \\
\end{array}$ & $\begin{array}{l}\mathrm{n}=1952 \\
\text { Response = } \\
82.4 \% \\
\text { Age }=>49\end{array}$ & $\begin{array}{l}\text { BRVO and } \\
\text { CRVO }\end{array}$ & $\begin{array}{l}\text { Non- } \\
\text { significant }\end{array}$ & $\begin{array}{l}\text { Non- } \\
\text { significant }\end{array}$ & $\begin{array}{l}\text { OR } 3.37 \\
(1.40-8.13)\end{array}$ & $\begin{array}{l}\text { OR } 4.09 \text { (1.80- } \\
9.50)\end{array}$ & $\begin{array}{l}\text { OR 4.89 } \\
(2.00-12.1)\end{array}$ & - \\
\hline $\begin{array}{l}\text { Klein } 2000^{161} \\
\text { American }\end{array}$ & $\begin{array}{l}\text { Population- } \\
\text { based } \\
\text { Cross- } \\
\text { sectional }\end{array}$ & $\begin{array}{l}\mathrm{n}=4926 \\
\text { Response = } \\
83.1 \% \\
\text { Age }=43-84\end{array}$ & BRVO & - & - & $\begin{array}{l}\text { OR 16.8 } \\
(7.33-38.2)\end{array}$ & $\begin{array}{l}\text { OR } 22.9 \text { (8.43- } \\
62.0)\end{array}$ & - & - \\
\hline $\begin{array}{l}\text { Klein } 2000^{161} \\
\text { American }\end{array}$ & $\begin{array}{l}\text { Population- } \\
\text { based } \\
\text { Longitudinal } \\
5 \text { year } \\
\text { Incidence }\end{array}$ & $\begin{array}{l}\mathrm{n}=3684 \\
\text { Response }= \\
83.1 \% \\
\text { Age }=43-84\end{array}$ & BRVO & - & - & $\begin{array}{l}\text { OR 5.24 } \\
(1.97-13.9)\end{array}$ & - & - & - \\
\hline $\begin{array}{l}\text { Cheung } \\
2008^{165} \\
\text { American }\end{array}$ & $\begin{array}{l}\text { Population- } \\
\text { based } \\
\text { Cross- } \\
\text { sectional }\end{array}$ & $\begin{array}{l}\mathrm{n}=6147 \\
\text { Response = } \\
94.6 \% \\
\text { Age }=45-84\end{array}$ & $\begin{array}{l}\text { BRVO and } \\
\text { CRVO }\end{array}$ & - & - & $\begin{array}{l}\text { OR 4.38 } \\
(1.44-13.3)\end{array}$ & $\begin{array}{l}\text { OR } 4.01 \\
(2.06-7.81)\end{array}$ & - & - \\
\hline $\begin{array}{l}\text { Wong } \\
2005^{166} \\
\text { American }\end{array}$ & $\begin{array}{l}\text { Population- } \\
\text { based } \\
\text { Cross- } \\
\text { sectional }\end{array}$ & $\begin{array}{l}\mathrm{n}=15466 \\
\text { Pooled data } \\
\text { sets } \\
\text { Age }=45- \\
64,>65\end{array}$ & $\begin{array}{l}\text { BRVO and } \\
\text { CRVO }\end{array}$ & $\begin{array}{l}\text { Non- } \\
\text { significant }\end{array}$ & - & $\begin{array}{l}\text { OR 5.17 } \\
(2.59-10.3)\end{array}$ & $\begin{array}{l}\text { OR } 4.09 \text { (2.00- } \\
8.36)\end{array}$ & - & - \\
\hline $\begin{array}{l}\text { Youm } \\
2012^{167}\end{array}$ & $\begin{array}{l}\text { Hospital- } \\
\text { based }\end{array}$ & $\begin{array}{l}\mathrm{n}=10890 \\
\text { Response }=\end{array}$ & BRVO & $p=0.004$ & $p=0.001 \dagger$ & - & - & - & - \\
\hline
\end{tabular}




\begin{tabular}{|c|c|c|c|c|c|c|c|c|c|}
\hline $\begin{array}{l}\text { South } \\
\text { Korean }\end{array}$ & $\begin{array}{l}\text { Cross- } \\
\text { sectional }\end{array}$ & $\begin{array}{l}91.5 \% \\
\text { Age }=>50\end{array}$ & & & & & & & \\
\hline $\begin{array}{l}\text { Lim } 2008^{184} \\
\text { Malay } \\
\text { Singaporean }\end{array}$ & $\begin{array}{l}\text { Population- } \\
\text { based } \\
\text { Cross- } \\
\text { sectional }\end{array}$ & $\begin{array}{l}\mathrm{n}=3265 \\
\text { Response }= \\
78.7 \% \\
\text { Age }=40-80\end{array}$ & $\begin{array}{l}\text { BRVO and } \\
\text { CRVO }\end{array}$ & $\begin{array}{l}\text { Non- } \\
\text { significant }\end{array}$ & $\begin{array}{l}\text { Non- } \\
\text { significant }\end{array}$ & - & - & - & - \\
\hline
\end{tabular}

Table 3: Summary of the prevalent and incident associations between retinal vein occlusion and retinal microvascular maladaptations.

OR $=$ Odds Ratio with 95\% confidence interval. BRVO = Branch retinal vein occlusion. CRVO = central retinal vein occlusion. †Associations reported for narrower venular calibre rather than wider calibre. 
The effects of treatment on the microvasculature in those with RVO have also been assessed. A relative venodilation of unaffected vessels during recent branch RVO has been demonstrated which is theorised to occur due to increased venous flow in the patent vessels and by concurrent nitric oxide and VEGF dependent mechanisms driven by the ischaemic retina ${ }^{192}$. Clinic-based studies have shown that the development of macular oedema in eyes with RVO results in retinal venodilation compared to those without macular oedema191,192. Treatment of macular oedema with intravitreal anti-VEGF agents or argon laser photocoagulation has showed that these treatments reverse the effects of hypoxia and other vaso-active mediators; resulting in both arteriolar ${ }^{193}$ and venular constriction ${ }^{191-195}$. Another small study found that photocoagulation laser in subjects with branch retinal vein occlusion resulted in narrowing of the occluded venule and its adjacent artery however the vascular calibre in the unaffected hemisphere remained unchanged ${ }^{196}$. It remains to be determined whether this iatrogenic vasoconstriction causes a pathological impedance to microvascular retinal flow or return to an adapted pre-morbid physiology86,193,195. Further study may also determine whether a role exists for assessment of microvascular characteristics in those with RVO to predict the development of macular oedema or in predicting treatment response.

\section{RETI NAL ARTERI OLAR EMBOLI AND OCCLUSI ON}

In population-based studies, investigators have assessed retinal microvascular characteristics and cardiovascular risk factors based on the detection of asymptomatic retinal emboli on fundus photography rather than the specific study of patients following amaurosis fugax or retinal arterial occlusion in a clinical setting. The results show that smoking, hypertension, and ipsilateral carotid disease are the more consistent risk factors for the development of retinal emboli166,197-199. Retinal artery occlusion is also associated with these risk factors ${ }^{200-203}$. The presence of retinal artery embolism or occlusion predicts higher rates of cerebrovascular mortality independent of other cardiovascular risk factors ${ }^{198,200-203 .}$ 
Though less frequently reported than the other retinal vascular disease states, there is no evidence of associations between retinal microvascular changes and prevalent or incident retinal embolism ${ }^{166,204-208}$ (Table 4). This is with the exception of the Beaver Dam Eye Study where at the 5 year analysis, the presence of retinopathy in non-diabetic subjects had a fourfold higher risk of prevalent embolism ${ }^{204}$ however no measures were associated with incident emboli at either the 5 or 10 year analysis ${ }^{205}$. The parameters of AV nicking, focal and generalised arteriolar narrowing 


\begin{tabular}{|c|c|c|c|c|c|c|c|c|c|}
\hline & & & & \multicolumn{6}{|c|}{ Reported Associations With Retinal Microvascular Indices } \\
\hline Study & Design & Population & Characteristic & $\begin{array}{l}\text { Narrowed } \\
\text { Arteriolar } \\
\text { Calibre }\end{array}$ & \begin{tabular}{|l|} 
Widened \\
Venular \\
Calibre \\
\end{tabular} & \begin{tabular}{|l|} 
Focal \\
Arteriolar \\
Narrowing \\
\end{tabular} & $\begin{array}{l}\text { Arteriovenous } \\
\text { Nicking }\end{array}$ & \begin{tabular}{|l|} 
Vessel Wall \\
Opacification
\end{tabular} & $\begin{array}{l}\text { Fractal } \\
\text { Dimension }\end{array}$ \\
\hline $\begin{array}{l}\text { Wong } \\
2005^{166} \\
\text { American }\end{array}$ & $\begin{array}{l}\text { Population- } \\
\text { based } \\
\text { Cross- } \\
\text { sectional }\end{array}$ & $\begin{array}{l}\mathrm{n}=15466 \\
\text { Pooled data } \\
\text { sets } \\
\text { Age }=45- \\
64,>65\end{array}$ & Retinal Emboli & $\begin{array}{l}\text { Non- } \\
\text { significant }\end{array}$ & - & $\begin{array}{l}\text { OR 1.39 } \\
(0.57-3.39)\end{array}$ & $\begin{array}{l}\text { OR } 1.21(0.47- \\
3.15)\end{array}$ & - & - \\
\hline $\begin{array}{l}\text { Klein } 1999^{204} \\
\text { American }\end{array}$ & $\begin{array}{l}\text { Population- } \\
\text { based } \\
\text { Cross- } \\
\text { sectional }\end{array}$ & $\begin{array}{l}\mathrm{n}=4926 \\
\text { Response }= \\
83.1 \% \\
\text { Age }=43-84\end{array}$ & Retinal Emboli & - & - & $\begin{array}{l}\text { Non- } \\
\text { significant }\end{array}$ & Non-significant & - & - \\
\hline $\begin{array}{l}\text { Klein } 1999^{204} \\
\text { American }\end{array}$ & $\begin{array}{l}\text { Population- } \\
\text { based } \\
\text { Longitudinal } \\
5 \text { year } \\
\text { incidence }\end{array}$ & $\begin{array}{l}\mathrm{n}=3684 \\
\text { Response = } \\
83.1 \% \\
\text { Age }=43-84\end{array}$ & Retinal Emboli & - & - & $\begin{array}{l}\text { OR } 1.18 \\
(0.34-4.17)\end{array}$ & Non-significant & - & - \\
\hline $\begin{array}{l}\text { Klein } 2003^{205} \\
\text { American }\end{array}$ & $\begin{array}{l}\text { Population- } \\
\text { based } \\
\text { Longitudinal } \\
10 \text { year } \\
\text { incidence }\end{array}$ & $\begin{array}{l}\mathrm{n}=2764 \\
\text { Response }= \\
83.1 \% \\
\text { Age }=43-84\end{array}$ & Retinal Emboli & $\begin{array}{l}\text { Non- } \\
\text { significant }\end{array}$ & - & $\begin{array}{l}\text { OR } 0.75 \\
(0.22-2.50) \\
p=0.64\end{array}$ & Non-significant & - & - \\
\hline $\begin{array}{l}\text { Cheung } \\
2008^{206} \\
\text { Malay } \\
\text { Singaporean }\end{array}$ & $\begin{array}{l}\text { Population- } \\
\text { based } \\
\text { Cross- } \\
\text { sectional }\end{array}$ & $\begin{array}{l}\mathrm{n}=3265 \\
\text { Response = } \\
78.7 \% \\
\text { Age }=40-80\end{array}$ & Retinal Emboli & $\begin{array}{l}\text { Non- } \\
\text { significant }\end{array}$ & $\begin{array}{l}\text { Non- } \\
\text { significant }\end{array}$ & - & - & - & - \\
\hline $\begin{array}{l}\text { Cugati } \\
2006^{208} \\
\text { Australian }\end{array}$ & $\begin{array}{l}\text { Population- } \\
\text { based } \\
\text { Longitudinal } \\
10 \text { year } \\
\text { incidence }\end{array}$ & $\begin{array}{l}\mathrm{n}=1952 \\
\text { Response }= \\
82.4 \% \\
\text { Age }=>49\end{array}$ & Retinal Emboli & - & - & $\begin{array}{l}\text { OR 2.12 } \\
(0.89-5.05)\end{array}$ & $\begin{array}{l}\text { OR } 2.26 \text { (1.30- } \\
3.92)\end{array}$ & $\begin{array}{l}\text { OR 3.44 } \\
(1.55-7.65)\end{array}$ & - \\
\hline
\end{tabular}


Table 4: Summary of the prevalent and incident associations between asymptomatic retinal arteriolar emboli and retinal microvascular maladaptations.

$\mathrm{OR}=$ Odds Ratio with 95\% confidence interval.

This article is protected by copyright. All rights reserved. 
were also not predictive of incident retinal emboli after 10 years ${ }^{205}$. The Blue Mountains Eye Study showed that $18 \%$ of people with retinal emboli compared to $12 \%$ without had non-diabetic retinopathy lesions but the statistical significance was unreported ${ }^{197}$. The 10 year follow-up of the BMES cohort showed that AV nicking, arteriolar wall opacification and retinal vein occlusion predict incident retinal embolism ${ }^{208}$. Other microvascular parameters such as focal or general arteriolar narrowing have not shown association with the presence of retinal emboli so far in cross-sectional or prospective population-based studies.

The lack of association may be due to bias in the aforementioned studies due to the transient nature of asymptomatic emboli, however the magnitude of any attenuation of results remains unknown. Other static microvascular measures such as vascular geometric indices may yet reveal an association with retinal emboli however this has not been examined to date. The relationship of retinal microvascular maladaptations and carotid disease including intima-media thickness (IMT) and plaque also remains tenuous $22,166,209-212$. Wong and colleagues have been the sole investigators to evaluate the link between carotid disease and retinal emboli in a cross-sectional population-based design finding a significant association with the presence of carotid plaque and a borderline relationship with carotid IMT ( $P$ test of trend $=0.051)^{166}$.

\section{ABETI C RETI NOPATHY}

Diabetic retinopathy remains the most common retinal vascular disease and its associations with retinal microvascular changes from large population-based studies have been extensively reported. Multiple review articles summarising the retinal microvascular associations in diabetes for both the adult and the paediatric population have been published $26,27,31,35,212-220$. These reviews have typically addressed four key associations; first the microvascular maladaptations predicting disease in non-diabetics, second the prevalent microvascular characteristics in those with diabetes, third the predictors of incident and progression of retinopathy, and fourth the differences in the microvasculature in diabetics with retinopathy compared to those without retinopathy. Three prospective population-based studies revealed 
that arteriolar narrowing was predictive of diabetes development ${ }^{221-223}$, with the Rotterdam Study alternatively concluding that venular widening was associated with incident diabetes ${ }^{81}$. Arteriolar dilation is almost ubiquitously associated with prevalent diabetes, impaired glucose tolerance, and impaired fasting glucose, with venular widening also showing a significant correlation especially in the study of type 1 diabetes ${ }^{27,216}$. Retinal vascular calibre has generally not been a reliable predictor of incident diabetic retinopathy with seemingly discordant results reported in the type 1 diabetic population and largely non-significant associations found in individuals with type 2 diabetes ${ }^{27,213}$. Studies in the type 1 diabetic population determined that wider arterioles $224-226$ and venules 224,227 were predictive of progression of retinopathy. Longitudinal pooled data from 1098 persons with both type 1 and type 2 diabetes revealed that widening CRVE between examinations was associated with both the incidence and progression of retinopathy as well as increased incidence of macular oedema and proliferative retinopathy ${ }^{228}$. Some cross-sectional studies have additionally shown that venular dilatation correlates with the presence of retinopathy in both type 1 and type 2 diabetes $229-232$.

Static retinal geometric indices and dynamic assessments of the microvasculature have been examined more comprehensively in the study of diabetes than the aforementioned ophthalmic disease states. Dynamic assessment of the microvasculature has revealed an impaired vasodilation response to diffuse luminance flicker in diabetic eyes with similar vascular calibre to controls, therefore possibly predicting an impaired functional response of the vascular and neuronal retinal elements, preceding changes in vascular calibre $26,34,233,234$. When correlated to vessel calibre, wider arteriolar and venular diameter were associated with worse flicker-induced vasodilation responses in diabetic eyes ${ }^{235}$. The retinal vessels in diabetic eyes have also demonstrated an impaired myogenic response in response to increased intra-luminal pressure ${ }^{26}$. In addition to calibre measurements, vascular geometric indices have featured prominently in the study of the diabetic retina. The assessment of vascular geometry is based on measurements of the departure of the branching pattern of the retinal vessels from an ideal arrangement in which retinal blood flow is optimized and endothelial shear stress is minimised. These measures, 
including vessel tortuosity, branching angle, optimality deviation, length-to-diameter ratio, and lower fractal dimension have shown association with both incident and prevalent diabetes and diabetic retinopathy $26,27,31,212$. There is sparse data comparing the predictive capacity of these geometric indices with vascular diameter measurements ${ }^{27}$. It is plausible that these dynamic and static geometric indices may develop a role in the assessment of the risk of diabetic retinopathy particularly in type 2 diabetes where the literature at present does not reveal strong correlations with vessel calibre.

The effects of the treatments for diabetic macular oedema and proliferative diabetic retinopathy have also been assessed with respect to retinal microvascular characteristics in clinic-based cohorts. With further investigation, retinal vessel maladaptations may one day feature as biomarkers of treatment response. Wider baseline CRVE has been shown to predict improvement in visual acuity at twelve months in those treated with intravitreal ranibizumab for DMO in a small clinic-based study ${ }^{236}$, in contrast to the prediction of poor visual outcome in those treated for neovascular AMD ${ }^{89}$. Tatlipinar and colleagues however did not demonstrate a statistically significant change in arteriolar or venular calibre in eyes with DMO treated with a single dose of bevacizumab after one month of surveilance ${ }^{85}$. Another study of ten eyes with DMO treated with three consecutive injections of bevacizumab also demonstrated a non-significant trend toward narrowing of the microvasculature ${ }^{237}$. Intravitreal triamcinolone has been shown to have a vasoconstrictive effect on arterioles and venules in eyes with DMO in addition to a corresponding improvement in visual acuity 238,239 . Macular grid laser photocoagulation for DMO has been shown to have only localised effects of macular arterioles and venules rather than generalised vessel calibre in contrast to the aforementioned intravitreal treatments ${ }^{240,241}$. Panretinal photocoagulation has been associated with generalised ateriolar and venular calibre narrowing which is theorised to occur via autoregulatory constriction following improved oxygenation of the inner retina subsequent to photoreceptor destruction 231,232,242-244. Topical latanoprost has been shown to induce retinal arteriolar narrowing in a small cohort of twenty-two persons with type 1 diabetes however this did not correlate with a 
reduction in central retinal thickness with the authors advocating for further prospective study to assess whether this arterial constriction will translate into better outcomes in retinal hyperperfusion disease states ${ }^{156}$. The effect of oral hypoglycaemics on the retinal microvasculature has been infrequently investigated and remains unreported in population-based studies ${ }^{143,144}$. Oral vildagliptin when used in addition to metformin in those with type 2 diabetes resulted in a reduction in arteriolar wall-to-lumen ratio after six months of therapy in a clinic-based cohort ${ }^{245}$.

\section{NI CAL I MPLI CATI ONS}

Further confirmation studies may be required to determine the true associations between retinal microvascular characteristics and both ophthalmic and systemic diseases. Population-based studies have typically utilised similar imaging methodologies, however exhibit differences in disease definitions, population, cohort size, demographics, and follow-up regimens. Once more consistent trends emerge from the population data, these microvascular indices may be utilised to improve the accuracy of existing established risk stratification tools. This has been demonstrated by investigators to improve the risk stratification of stroke by approximately ten percent beyond that of using established cardiovascular risk factors alone ${ }^{15,27,30}$. McClintic and colleagues have additionally recommended that retinal microvascular assessment may enhance stratification of coronary artery disease risk in women with one Framingham risk factor ${ }^{18}$. Recognition of the importance of identifying these microvascular changes has led to recommendations regarding the scheduling of ocular examinations by ophthalmologists with suggested management strategies to minimise a patients' systemic cardiovascular risk based on these microvascular findings $18,20,246$. Incorporation increasing venular calibre over time has already been shown to enhance the prediction of the incidence and progression of diabetic retinopathy compared to traditional methods ${ }^{228}$.

Further study is required to validate the role of routine retinal microvascular analysis to determine an undifferentiated individual's risk of eye or systemic disease. A significant barrier to widespread implementation of this imaging technology is the 
absence of an absolute risk for a given microvascular parameter ${ }^{212}$. Despite the absence of this data, in diabetic individuals alterations in vessel calibre over time may prove efficacious as a surrogate biomarker of an individuals glycaemic control and risk of retinopathy ${ }^{27,228,247}$. It remains to be seen whether these enhanced risk prediction models are able to translate into clinical practice in a way which is efficient for the practitioner, offers improved diagnostic and predictive capacity over existing methods, is cost-effective, and preserves both the vision and systemic health of the patient by way of early prevention and intervention initiatives $92,212,228,248,249$.

Intervention studies undertaken in clinic-based cohorts have provided evidence of microvascular remodelling in response to local treatments, suggesting that retinal vessel diameter may be a surrogate marker of disease severity, and an independent predictor of treatment response. Retinal microvascular indices may also be useful as a marker of systemic treatment efficacy as studies have validated the effect of lifestyle modifications and smoking cessation on reversing retinal microvascular maladaptations ${ }^{250-252}$. Systemic treatment has also been shown to improve vascular indices in hypertensive patients initiated on anti-hypertensive therapy, particularly dihydropyridine calcium channel blockers and angiotensin converting enzyme (ACE) inhibitors ${ }^{253-256}$. Similarly, arteriolar dilation has been demonstrated in persons treated with statins (hydroxymethylglutaryl-CoA reductase inhibitors) ${ }^{257}$. These observations are consistent with data from the BMES where anti-hypertensive use, particularly calcium channel blockers were associated with wider arterioles ${ }^{144}$. The use of ACE inhibitors, thiazide diuretics and lipid-lowering therapies have also demonstrated cross-sectional associations with wider arterioles ${ }^{143}$. The therapeutic interventions for diabetes including oral hypogycaemics and insulin may also be shown to independently reverse adverse retinal microvascular changes in the future. Interventions which reverse maladaptation of the retinal microvasculature may provide evidence of potential mechanisms of disease and also serve as a surrogate marker of risk reduction of both ophthalmic and systemic disease in treated individuals. Though improvement in the retinal vasculature in response to systemic treatment is observed and may benefit a younger demographic where vasomotor 
function is maintained, the independent benefit of vascular remodelling has not been studied compared with other established endpoints ${ }^{14,254}$.

\section{CONCLUSI ONS}

Retinal microvascular indices have demonstrated significant correlations with incident and prevalent ophthalmic disease independent of established cardiovascular risk factors. The studies so far have revealed strong prevalent associations of arteriolar narrowing with glaucomatous and non-glaucomatous optic neuropathy independent of intra-ocular pressure, as well as arteriolar dilatation in prevalent diabetes. Arteriosclerotic structural alterations, especially focal arteriolar narrowing, have demonstrated consistent associations with both prevalent and incident retinal vein occlusion. To date there has not been compelling evidence of a link between generalised vascular calibre and retinal arteriolar emboli or AMD in population-based studies. Abnormal vascular geometry and impaired dynamic functional responses of the retinal vessels are also being increasingly reported in the study of diabetes and diabetic retinopathy.

It is hoped that these indices may one day be able to predict the development or progression of eye disease with sufficient efficacy to allow early implementation of effective prevention and intervention strategies. Further extrapolation of the relationships between microvascular maladaptation and ophthalmic diseases may lead to advances in the understanding of the pathophysiology of these diseases, and aid in the development of targeted therapies. Further population-based confirmation studies are needed to validate the true associations of retinal microvascular alterations with ophthalmic disease before these potential biomarkers are able to be adopted into routine care and become established as clinical endpoints in themselves. In the future these retinal imaging techniques may also become utilised in monitoring the effectiveness of intervention strategies and also in the prediction of treatment response.

\section{METHOD OF LITERATURE SEARCH}


Searches were conducted using PubMed (United States National Library of Medicine and National Institutes of Health), MEDLINE (via EBSCOhost), Google Scholar, and ScienceDirect databases. Key words were utilised in the search strategy including: 'retinal', 'microvascular', 'vascular', 'arteriole', 'venule', 'calibre', and 'diameter'. These were coupled with the relevant descriptors including: 'macular degeneration', 'glaucoma', 'neuropathy', 'vein occlusion', 'emboli', 'diabetes', and 'retinopathy' according to the topic being searched. Words were truncated and used in conjunction with the appropriate Boolean operators to enhance the search results. Key sentinel population-based studies were searched individually as well as the bibliographies of each of the identified sources. No year restrictions were placed on any of the searches. 


\section{REFERENCES}

1. Catita J, López-Luppo M, Ramos D, Nacher V, Navarro M, Carretero A, Sánchez-Chardi A, Mendes-J orge L, Rodriguez-Baeza A, Ruberte J. I maging of cellular aging in human retinal blood vessels. Experimental Eye Research 2015; 135: 14-25.

2. Snell RS, Lemp MA. Clinical Anatomy of the Eye. Oxford: Blackwell Science Ltd, 1998.

3. Kur J, Newman EA, Chan-Ling T. Cellular and physiological mechanisms underlying blood flow regulation in the retina and choroid in health and disease. Progress In Retinal And Eye Research 2012; 31: 377-406.

4. Oyster CW. The Human Eye: Structure and Function. Massachusetts: Sinauer Associates Inc., 1999.

5. Goto I, Katsuki S, I kui H, Kimoto K, Mimatsu T. Pathological studies on the intracerebral and retinal arteries in cerebrovascular and noncerebrovascular diseases. Stroke; A Journal Of Cerebral Circulation 1975; 6: 263-9.

6. Wong TY. Is retinal photography useful in the measurement of stroke risk? The Lancet Neurology 2004; 3: 179-83.

7. Kwa $\mathrm{VIH}$. Our eyes: windows to our souls or crystal balls? The Lancet Neurology 2006; 5: 108-10.

8. Tedeschi-Reiner E, Strozzi M, Skoric B, Reiner Z. Relation of atherosclerotic changes in retinal arteries to the extent of coronary artery disease. The American Journal Of Cardiology 2005; 96: 1107-9.

9. Patton N, Aslam T, Macgillivray T, Pattie A, Deary IJ, Dhillon B. Retinal vascular image analysis as a potential screening tool for cerebrovascular disease: a rationale based on homology between cerebral and retinal microvasculatures. Journal Of Anatomy 2005; 206: 319-48.

10. Chew SKH, Xie J, Wang JJ. Retinal arteriolar diameter and the prevalence and incidence of hypertension: a systematic review and meta-analysis of their association. Current Hypertension Reports 2012; 14: 144-51.

11. Wong TY, Klein R, Couper DJ, Cooper LS, Shahar E, Hubbard LD, Wofford MR, Sharrett AR. Retinal microvascular abnormalities and incident stroke: the 
Atherosclerosis Risk in Communities Study. Lancet (London, England) 2001; 358: $1134-40$.

12. Wong TY, Klein R, Nieto FJ, Klein BEK, Sharrett AR, Meuer SM, Hubbard LD, Tielsch J M. Retinal microvascular abnormalities and 10-year cardiovascular mortality: a population-based case-control study. Ophthalmology 2003; 110: 933-40.

13. Wong TY, Klein R, Sharrett AR, Duncan BB, Couper DJ, Tielsch JM, Klein BEK, Hubbard LD. Retinal arteriolar narrowing and risk of coronary heart disease in men and women. The Atherosclerosis Risk in Communities Study. JAMA 2002; 287: 1153-9.

14. Ding J, Wai KL, McGeechan K, Ikram MK, Kawasaki R, Xie J, Klein R, Klein BBK, Cotch MF, Wang JJ, Mitchell P, Shaw JE, Takamasa K, Sharrett AR, Wong TY. Retinal vascular caliber and the development of hypertension: a meta-analysis of individual participant data. Journal Of Hypertension 2014; 32: 207-15.

15. McGeechan K, Liew G, Macaskill P, Irwig L, Klein R, Klein BEK, Wang JJ, Mitchell P, Vingerling JR, de J ong PTVM, Witteman JCM, Breteler MMB, Shaw J, Zimmet P, Wong TY. Prediction of incident stroke events based on retinal vessel caliber: a systematic review and individual-participant meta-analysis. American Journal Of Epidemiology 2009; 170: 1323-32.

16. Doubal FN, Hokke PE, Wardlaw JM. Retinal microvascular abnormalities and stroke: a systematic review. Journal Of Neurology, Neurosurgery, And Psychiatry 2009; 80: 158-65.

17. McGeechan K, Liew G, Macaskill P, Irwig L, Klein R, Klein BEK, Wang JJ, Mitchell P, Vingerling J R, Dejong PTVM, Witteman JCM, Breteler MMB, Shaw J, Zimmet P, Wong TY. Meta-analysis: retinal vessel caliber and risk for coronary heart disease. Annals Of Internal Medicine 2009; 151: 404-13.

18. McClintic BR, McClintic JI, Bisognano JD, Block RC. The relationship between retinal microvascular abnormalities and coronary heart disease: a review. The American Journal Of Medicine 2010; 123: 374.e1-7.

19. Liew G, Wang JJ. [Retinal vascular signs: a window to the heart?]. Revista Española De Cardiología 2011; 64: 515-21. 
20. Wong TY, Mclntosh R. Hypertensive retinopathy signs as risk indicators of cardiovascular morbidity and mortality. British Medical Bulletin 2005; 73-74: 57-70.

21. Wang JJ, Liew G, Klein R, Rochtchina E, Knudtson MD, Klein BEK, Wong TY, Burlutsky G, Mitchell P. Retinal vessel diameter and cardiovascular mortality: pooled data analysis from two older populations. European Heart Journal 2007; 28: 1984-92.

22. Wong TY, Klein R, Klein BE, Tielsch J M, Hubbard L, Nieto FJ. Retinal microvascular abnormalities and their relationship with hypertension, cardiovascular disease, and mortality. Survey Of Ophthalmology 2001; 46: 59-80.

23. Li L-J, Lee Y-S, Wong T-Y, Cheung CY-L. Can the retinal microvasculature offer clues to cardiovascular risk factors in early life? Acta Paediatrica (Os/o, Norway: 1992) 2013; 102: 941-6.

24. Hubbard LD, Brothers RJ, King WN, Clegg LX, Klein R, Cooper LS, Sharrett AR, Davis MD, Cai J. Methods for evaluation of retinal microvascular abnormalities associated with hypertension/sclerosis in the Atherosclerosis Risk in Communities Study. Ophthalmology 1999; 106: 2269-80.

25. Knudtson MD, Lee KE, Hubbard LD, Wong TY, Klein R, Klein BEK. Revised formulas for summarizing retinal vessel diameters. Current Eye Research 2003; 27: 143-9.

26. I Iram MK, Cheung CY, Lorenzi M, Klein R, Jones TLZ, Wong TY. Retinal vascular caliber as a biomarker for diabetes microvascular complications. Diabetes Care 2013; 36: 750-9.

27. Cheung CY, I kram MK, Klein R, Wong TY. The clinical implications of recent studies on the structure and function of the retinal microvasculature in diabetes. Diabetologia 2015; 58: 871-85.

28. Cheung CY, Thomas GN, Tay W, I kram MK, Hsu W, Lee ML, Lau QP, Wong TY. Retinal vascular fractal dimension and its relationship with cardiovascular and ocular risk factors. American Journal Of Ophthalmology 2012; 154: 66374.e1. 
29. Cheung CY, Tay WT, Mitchell P, Wang JJ, Hsu W, Lee ML, Lau QP, Zhu AL, Klein R, Saw SM, Wong TY. Quantitative and qualitative retinal microvascular characteristics and blood pressure. Journal Of Hypertension 2011; 29: 138091.

30. Cheung CY-I, Tay WT, I kram MK, Ong YT, De Silva DA, Chow KY, Wong TY. Retinal microvascular changes and risk of stroke: the Singapore Malay Eye Study. Stroke; A Journal Of Cerebral Circulation 2013; 44: 2402-8.

31. Newman AR, Andrew NH, Casson RJ. Review of paediatric retinal microvascular changes as a predictor of cardiovascular disease. Clinical \& Experimental Ophthalmology 2017; 45: 33-44.

32. Cheung N, Donaghue KC, Liew G, Rogers SL, Wang JJ, Lim S-W, J enkins AJ, Hsu W, Li Lee M, Wong TY. Quantitative assessment of early diabetic retinopathy using fractal analysis. Diabetes Care 2009; 32: 106-10.

33. Cosatto VF, Liew G, Rochtchina E, Wainwright A, Zhang Y, Hsu W, Lee ML, Lau QP, Hamzah HH, Mitchell P, Wong TY, Wang JJ. Retinal vascular fractal dimension measurement and its influence from imaging variation: results of two segmentation methods. Current Eye Research 2010; 35: 850-6.

34. Lim M, Sasongko MB, Ikram MK, Lamoureux E, Wang JJ, Wong TY, Cheung CY. Systemic associations of dynamic retinal vessel analysis: a review of current literature. Microcirculation (New York, NY: 1994) 2013; 20: 257-68.

35. Sun C, Wang JJ, Mackey DA, Wong TY. Retinal vascular caliber: systemic, environmental, and genetic associations. Survey Of Ophthalmology 2009; 54: 74-95.

36. Tso MO, Jampol LM. Pathophysiology of hypertensive retinopathy. Ophthalmology 1982; 89: 1132-45.

37. Levin L, Nilsson S, Hoeve J, W S, Kaufman P, Alm A. Adler's Physiology of the Eye, 11th edn. Edingburg: Saunders/Elsevier, 2011.

38. Skalicky SE. Ocular and Visual Physiology: Clinical Application. Singapore: Springer, 2016.

39. Moore D, Harris A, Wudunn D, Kheradiya N, Siesky B. Dysfunctional regulation of ocular blood flow: A risk factor for glaucoma? Clinical Ophthalmology (Auckland, NZ) 2008; 2: 849-61. 
40. Delles C, Michelson G, Harazny J, Oehmer S, Hilgers KF, Schmieder RE. Impaired endothelial function of the retinal vasculature in hypertensive patients. Stroke 2004; 35: 1289-93.

41. Ikram MK, de J ong FJ, Vingerling JR, Witteman J CM, Hofman A, Breteler MMB, de Jong PTVM. Are retinal arteriolar or venular diameters associated with markers for cardiovascular disorders? The Rotterdam Study. Investigative Ophthalmology \& Visual Science 2004; 45: 2129-34.

42. Klein R, Klein BEK, Knudtson MD, Wong TY, Tsai MY. Are inflammatory factors related to retinal vessel caliber? The Beaver Dam Eye Study. Archives Of Ophthalmology (Chicago, IIl: 1960) 2006; 124: 87-94.

43. Wong TY, Islam FMA, Klein R, Klein BEK, Cotch MF, Castro C, Sharrett AR, Shahar E. Retinal vascular caliber, cardiovascular risk factors, and inflammation: the multi-ethnic study of atherosclerosis (MESA). Investigative Ophthalmology \& Visual Science 2006; 47: 2341-50.

44. Chester AH, Borland JA, Buttery LD, Mitchell JA, Cunningham DA, Hafizi S, Hoare GS, Springall DR, Polak J M, Yacoub MH. Induction of nitric oxide synthase in human vascular smooth muscle: interactions between proinflammatory cytokines. Cardiovascular Research 1998; 38: 814-21.

45. Boillot A, Zoungas S, Mitchell P, Klein R, Klein B, Ikram MK, Klaver C, Wang JJ, Gopinath B, Tai ES, Neubauer AS, Hercberg S, Brazionis L, Saw S-M, Wong T-Y, Czernichow S. Obesity and the microvasculature: a systematic review and meta-analysis. Plos One 2013; 8: e52708-e.

46. Shankar A, Sabanayagam C, Klein BEK, Klein R. Retinal microvascular changes and the risk of developing obesity: population-based cohort study. Microcirculation (New York, NY: 1994) 2011; 18: 655-62.

47. Wang JJ, Taylor B, Wong TY, Chua B, Rochtchina E, Klein R, Mitchell P. Retinal vessel diameters and obesity: a population-based study in older persons. Obesity (Silver Spring, Md) 2006; 14: 206-14.

48. Wong TY, Duncan BB, Golden SH, Klein R, Couper DJ, Klein BEK, Hubbard LD, Sharrett AR, Schmidt MI. Associations between the metabolic syndrome and retinal microvascular signs: the Atherosclerosis Risk In Communities study. Investigative Ophthalmology \& Visual Science 2004; 45: 2949-54. 
49. Kawasaki R, Tielsch J M, Wang JJ, Wong TY, Mitchell P, Tano Y, Tominaga M, Oizumi T, Daimon M, Kato T, Kawata S, Kayama T, Yamashita H. The metabolic syndrome and retinal microvascular signs in a Japanese population: the Funagata study. The British Journal Of Ophthalmology 2008; 92: 161-6.

50. Kolodjaschna J, Berisha F, Lung S, Schaller G, Polska E, J ilma B, Wolzt M, Schmetterer L. LPS-induced microvascular leukocytosis can be assessed by blue-field entoptic phenomenon. American Journal Of Physiology Heart And Circulatory Physiology 2004; 287: H691-H4.

51. Tamai K, Matsubara A, Tomida K, Matsuda Y, Morita H, Armstrong D, Ogura Y. Lipid hydroperoxide stimulates leukocyte-endothelium interaction in the retinal microcirculation. Experimental Eye Research 2002; 75: 69-75.

52. Donoso LA, Kim D, Frost A, Callahan A, Hageman G. The role of inflammation in the pathogenesis of age-related macular degeneration. Survey of Ophthalmology 2006; 51: 137-52.

53. Friedman E. The role of the atherosclerotic process in the pathogenesis of age-related macular degeneration. American Journal Of Ophthalmology 2000; 130: 658-63.

54. Yang K, Wang F-H, Liang Y-B, Wong T-Y, Wang J-J, Zhan S-Y, Wang N-L. Associations between cardiovascular risk factors and early age-related macular degeneration in a rural Chinese adult population. Retina (Philadelphia, Pa) 2014; 34: 1539-53.

55. Vingerling JR, Dielemans I, Bots ML, Hofman A, Grobbee DE, de Jong PT. Age-related macular degeneration is associated with atherosclerosis. The Rotterdam Study. American Journal Of Epidemiology 1995; 142: 404-9.

56. Yip JLY, Khawaja AP, Chan MPY, Broadway DC, Peto T, Tufail A, Luben R, Hayat S, Bhaniani A, Wareham NJ, Khaw K-T, Foster PJ. Cross Sectional and Longitudinal Associations between Cardiovascular Risk Factors and Age Related Macular Degeneration in the EPIC-Norfolk Eye Study. Plos One 2015; 10: e0132565-e.

57. Cackett P, Yeo I, Cheung CMG, Vithana EN, Wong D, Tay WT, Tai ES, Aung T, Wong TY. Relationship of smoking and cardiovascular risk factors with 
polypoidal choroidal vasculopathy and age-related macular degeneration in Chinese persons. Ophthalmology 2011; 118: 846-52.

58. Chakravarthy U, Wong TY, Fletcher A, Piault E, Evans C, Zlateva G, Buggage R, Pleil A, Mitchell P. Clinical risk factors for age-related macular degeneration: a systematic review and meta-analysis. BMC Ophthalmology 2010; 10: 31-.

59. Cackett $P$, Wong TY, Aung T, Saw S-M, Tay WT, Rochtchina E, Mitchell P, Wang JJ. Smoking, cardiovascular risk factors, and age-related macular degeneration in Asians: the Singapore Malay Eye Study. American Journal of Ophthalmology 2008; 146: 960-7.e1.

60. Tan J SL, Mitchell P, Smith W, Wang JJ. Cardiovascular risk factors and the long-term incidence of age-related macular degeneration: the Blue Mountains Eye Study. Ophthalmology 2007; 114: 1143-50.

61. Sun C, Klein R, Wong TY. Age-related macular degeneration and risk of coronary heart disease and stroke: the Cardiovascular Health Study. Ophthalmology 2009; 116: 1913-9.

62. Snow KK, Seddon JM. Do age-related macular degeneration and cardiovascular disease share common antecedents? Ophthalmic Epidemiology 1999; 6: 125-43.

63. Klein R, Deng Y, Klein BEK, Hyman L, Seddon J, Frank RN, Wallace RB, Hendrix SL, Kuppermann BD, Langer RD, Kuller L, Brunner R, Johnson KC, Thomas AM, Haan M. Cardiovascular disease, its risk factors and treatment, and age-related macular degeneration: Women's Health Initiative Sight Exam ancillary study. American Journal Of Ophthalmology 2007; 143: 473-83.

64. Hyman L, Schachat AP, He Q, Leske MC. Hypertension, cardiovascular disease, and age-related macular degeneration. Age-Related Macular Degeneration Risk Factors Study Group. Archives Of Ophthalmology (Chicago, III: 1960) 2000; 118: 351-8.

65. Klein R, Klein BEK, Knudtson MD, Cotch MF, Wong TY, Liu K, Burke GL, Saad MF, Jacobs DR, J r., Sharrett AR. Subclinical atherosclerotic cardiovascular disease and early age-related macular degeneration in a multiracial cohort: 
the Multiethnic Study of Atherosclerosis. Archives Of Ophthalmology (Chicago, II: 1960) 2007; 125: 534-43.

66. Delcourt C, Michel F, Colvez A, Lacroux A, Delage M, Vernet MH. Associations of cardiovascular disease and its risk factors with age-related macular degeneration: the POLA study. Ophthalmic Epidemiology 2001; 8: 237-49.

67. Fraser-Bell S, Wu J, Klein R, Azen SP, Hooper C, Foong AWP, Varma R. Cardiovascular risk factors and age-related macular degeneration: the Los Angeles Latino Eye Study. American Journal Of Ophthalmology 2008; 145: 308-16.

68. Wong TY, Tikellis G, Sun C, Klein R, Couper DJ, Sharrett AR. Age-related macular degeneration and risk of coronary heart disease: the Atherosclerosis Risk in Communities Study. Ophthalmology 2007; 114: 86-91.

69. Klein R, Klein BEK, Marino EK, Kuller LH, Furberg C, Burke GL, Hubbard LD. Early age-related maculopathy in the cardiovascular health study. Ophthalmology 2003; 110: 25-33.

70. Tomany SC, Wang JJ, Van Leeuwen R, Klein R, Mitchell P, Vingerling J R, Klein BEK, Smith W, De Jong PTVM. Risk factors for incident age-related macular degeneration: pooled findings from 3 continents. Ophthalmology 2004; 111: 1280-7.

71. Smith W, Assink J, Klein R, Mitchell P, Klaver CC, Klein BE, Hofman A, J ensen $\mathrm{S}$, Wang JJ, de Jong PT. Risk factors for age-related macular degeneration: Pooled findings from three continents. Ophthalmology 2001; 108: 697-704.

72. Wang JJ, Mitchell P, Rochtchina E, Tan AG, Wong TY, Klein R. Retinal vessel wall signs and the 5 year incidence of age related maculopathy: the Blue Mountains Eye Study. The British Journal Of Ophthalmology 2004; 88: 104-9.

73. J onasson F, Fisher DE, Eiriksdottir G, Sigurdsson S, Klein R, Launer LJ, Harris T, Gudnason V, Cotch MF. Five-year incidence, progression, and risk factors for age-related macular degeneration: the age, gene/environment susceptibility study. Ophthalmology 2014; 121: 1766-72.

74. Velilla S, García-Medina J J, García-Layana A, Dolz-Marco R, Pons-Vázquez S, Pinazo-Durán MD, Gómez-Ulla F, Arévalo JF, Díaz-Llopis M, Gallego-Pinazo R. 
Smoking and age-related macular degeneration: review and update. Journal Of Ophthalmology 2013; 2013: 895147-.

75. Chin YC, Wong TY, Cheung CMG, Cheung CY-L, Zheng Y, Mitchell P, Huang H, Wang JJ, I kram MK. Retinal vascular caliber and age-related macular degeneration in an Indian population from Singapore. Ophthalmic Epidemiology 2014; 21: 224-9.

76. $\mathrm{Xu} \mathrm{L,} \mathrm{Wang} \mathrm{S,} \mathrm{Li} \mathrm{Y,} \mathrm{J} \mathrm{onas} \mathrm{J} \mathrm{B.} \mathrm{Retinal} \mathrm{vascular} \mathrm{abnormalities} \mathrm{and} \mathrm{prevalence} \mathrm{of}$ age-related macular degeneration in adult Chinese: the Beijing Eye Study. American Journal Of Ophthalmology 2006; 142: 688-9.

77. Klein R, Klein BEK, Tomany SC, Wong TY. The relation of retinal microvascular characteristics to age-related eye disease: the Beaver Dam eye study. American Journal Of Ophthalmology 2004; 137: 435-44.

78. J Jeganathan VSE, Kawasaki R, Wang JJ, Aung T, Mitchell P, Saw S-M, Wong TY. Retinal vascular caliber and age-related macular degeneration: the Singapore Malay Eye Study. American Journal Of Ophthalmology 2008; 146: 954-9.e1.

79. Yang $K$, Zhan SY, Liang YB, Duan X, Wang F, Wong TY, Sun LP, Wang N-L. Association of dilated retinal arteriolar caliber with early age-related macular degeneration: the Handan Eye Study. Graefe's Archive For Clinical And Experimental Ophthalmology = Albrecht Von Graefes Archiv Für Klinische Und Experimentelle Ophthalmologie 2012; 250: 741-9.

80. Liew G, Kaushik S, Rochtchina E, Tan AG, Mitchell P, Wang JJ. Retinal vessel signs and 10-year incident age-related maculopathy: the Blue Mountains Eye Study. Ophthalmology 2006; 113: 1481-7.

81. I kram MK, van Leeuwen R, Vingerling JR, Hofman A, de J ong PTVM. Retinal vessel diameters and the risk of incident age-related macular disease: the Rotterdam Study. Ophthalmology 2005; 112: 548-52.

82. You QS, Xu L, Yang H, Li YB, Wang S, Wang JD, Zhang J S, Wang YX, J onas JB. Five-year incidence of age-related macular degeneration: the Beijing Eye Study. Ophthalmology 2012; 119: 2519-25.

83. Klein R, Clegg L, Cooper LS, Hubbard LD, Klein BE, King WN, Folsom AR. Prevalence of age-related maculopathy in the Atherosclerosis Risk in 
Communities Study. Archives Of Ophthalmology (Chicago, Ill: 1960) 1999;

117: $1203-10$.

84. Delaey C, Van De Voorde J. Regulatory mechanisms in the retinal and choroidal circulation. Ophthalmic Research 2000; 32: 249-56.

85. Tatlipinar S, Dinç UA, Yenerel NM, Görgün E. Short-term effects of a single intravitreal bevacizumab injection on retinal vessel calibre. Clinical \& Experimental Optometry 2012; 95: 94-8.

86. Papadopoulou DN, Mendrinos E, Mangioris G, Donati G, Pournaras CJ . Intravitreal ranibizumab may induce retinal arteriolar vasoconstriction in patients with neovascular age-related macular degeneration. Ophthalmology 2009; 116: 1755-61.

87. Micieli JA, Tsui E, Lam W-C, Brent MH, Devenyi RG, Hudson C. Retinal blood flow in response to an intravitreal injection of ranibizumab for neovascular age-related macular degeneration. Acta Ophthalmologica 2012; 90: e13-e20.

88. Mendrinos E, Mangioris G, Papadopoulou DN, Donati G, Pournaras CJ . Longterm results of the effect of intravitreal ranibizumab on the retinal arteriolar diameter in patients with neovascular age-related macular degeneration. Acta Ophthalmologica 2013; 91: e184-e90.

89. Wickremasinghe SS, Busija L, Guymer RH, Wong TY, Qureshi S. Retinal venular caliber predicts visual outcome after intravitreal ranibizumab injection treatments for neovascular AMD. Investigative Ophthalmology \& Visual Science 2012; 53: 37-41.

90. Hoehn R, Mirshahi A, Hoffmann EM, Kottler UB, Wild PS, Laubert-Reh D, Pfeiffer N. Distribution of intraocular pressure and its association with ocular features and cardiovascular risk factors: the Gutenberg Health Study. Ophthalmology 2013; 120: 961-8.

91. Mitchell $\mathrm{P}$, Leung $\mathrm{H}$, Wang JJ, Rochtchina E, Lee AJ, Wong TY, Klein R. Retinal vessel diameter and open-angle glaucoma: the Blue Mountains Eye Study. Ophthalmology 2005; 112: 245-50.

92. Amerasinghe N, Aung T, Cheung N, Fong CW, Wang JJ, Mitchell P, Saw S-M, Wong TY. Evidence of retinal vascular narrowing in glaucomatous eyes in an 
Asian population. Investigative Ophthalmology \& Visual Science 2008; 49: 5397-402.

93. Zheng Y, Cheung N, Aung T, Mitchell P, He M, Wong TY. Relationship of retinal vascular caliber with retinal nerve fiber layer thickness: the singapore malay eye study. Investigative Ophthalmology \& Visual Science 2009; 50: 4091-6.

94. Hayreh SS. The role of age and cardiovascular disease in glaucomatous optic neuropathy. Survey Of Ophthalmology 1999; 43 Suppl 1: S27-S42.

95. Leske MC, Wu S-Y, Hennis A, Honkanen R, Nemesure B. Risk factors for incident open-angle glaucoma: the Barbados Eye Studies. Ophthalmology 2008; 115: 85-93.

96. Bonomi L, Marchini G, Marraffa M, Bernardi P, Morbio R, Varotto A. Vascular risk factors for primary open angle glaucoma: the Egna-Neumarkt Study. Ophthalmology 2000; 107: 1287-93.

97. Flammer J, Orgül S, Costa VP, Orzalesi N, Krieglstein GK, Serra LM, Renard JP, Stefánsson E. The impact of ocular blood flow in glaucoma. Progress In Retinal And Eye Research 2002; 21: 359-93.

98. Flammer J, Mozaffarieh M. What is the present pathogenetic concept of glaucomatous optic neuropathy? Survey Of Ophthalmology 2007; 52 Suppl 2: S162-S73.

99. I kram MK, de Voogd S, Wolfs RCW, Hofman A, Breteler MMB, Hubbard LD, de J ong PTVM. Retinal vessel diameters and incident open-angle glaucoma and optic disc changes: the Rotterdam study. Investigative Ophthalmology \& Visual Science 2005; 46: 1182-7.

100. Salim S, Shields MB. Glaucoma and systemic diseases. Survey Of Ophthalmology 2010; 55: 64-77.

101. Lee AJ, Wang JJ, Kifley A, Mitchell P. Open-angle glaucoma and cardiovascular mortality: the Blue Mountains Eye Study. Ophthalmology 2006; 113: 1069-76.

102. Lin H-C, Chien C-W, Hu C-C, Ho J-D. Comparison of comorbid conditions between open-angle glaucoma patients and a control cohort: a case-control study. Ophthalmology 2010; 117: 2088-95. 
103. Ho J-D, Hu C-C, Lin H-C. Open-angle glaucoma and the risk of stroke development: a 5-year population-based follow-up study. Stroke; A Journal of Cerebral Circulation 2009; 40: 2685-90.

104. Dielemans I, de Jong PT, Stolk R, Vingerling JR, Grobbee DE, Hofman A. Primary open-angle glaucoma, intraocular pressure, and diabetes mellitus in the general elderly population. The Rotterdam Study. Ophthalmology 1996; 103: 1271-5.

105. Klein BE, Klein R, J ensen SC. Open-angle glaucoma and older-onset diabetes. The Beaver Dam Eye Study. Ophthalmology 1994; 101: 1173-7.

106. Mitchell P, Smith W, Chey T, Healey PR. Open-angle glaucoma and diabetes: the Blue Mountains eye study, Australia. Ophthalmology 1997; 104: 712-8.

107. Pache M, Flammer J. A sick eye in a sick body? Systemic findings in patients with primary open-angle glaucoma. Survey Of Ophthalmology 2006; 51: 179212.

108. de Voogd S, Wolfs RCW, Jansonius NM, Witteman JCM, Hofman A, de Jong PTVM. Atherosclerosis, C-reactive protein, and risk for open-angle glaucoma: the Rotterdam study. Investigative Ophthalmology \& Visual Science 2006; 47: 3772-6.

109. de Voogd S, I kram MK, Wolfs RCW, J ansonius NM, Witteman JCM, Hofman A, de J ong PTVM. Is diabetes mellitus a risk factor for open-angle glaucoma? The Rotterdam Study. Ophthalmology 2006; 113: 1827-31.

110. Klein BE, Klein R, Ritter LL. Relationship of drinking alcohol and smoking to prevalence of open-angle glaucoma. The Beaver Dam Eye Study. Ophthalmology 1993; 100: 1609-13.

111. Tielsch J M, Katz J, Quigley HA, Javitt J C, Sommer A. Diabetes, intraocular pressure, and primary open-angle glaucoma in the Baltimore Eye Survey. Ophthalmology 1995; 102: 48-53.

112. Wang $S, X u L$, Wang $Y$, Wang $Y$, J onas J B. Retinal vessel diameter in normal and glaucomatous eyes: the Beijing eye study. Clinical \& Experimental Ophthalmology 2007; 35: 800-7. 
113. J onas J B, Nguyen XN, Naumann GO. Parapapillary retinal vessel diameter in normal and glaucoma eyes. I. Morphometric data. Investigative Ophthalmology \& Visual Science 1989; 30: 1599-603.

114. Jonas JB, Naumann GO. Parapapillary retinal vessel diameter in normal and glaucoma eyes. II. Correlations. Investigative Ophthalmology \& Visual Science 1989; 30: 1604-11.

115. Hall JK, Andrews AP, Walker R, Piltz-Seymour JR. Association of retinal vessel caliber and visual field defects in glaucoma. American Journal of Ophthalmology 2001; 132: 855-9.

116. Rankin SJ, Drance SM. Peripapillary focal retinal arteriolar narrowing in open angle glaucoma. Journal Of Glaucoma 1996; 5: 22-8.

117. Papastathopoulos $\mathrm{KI}$, J onas J B. Follow up of focal narrowing of retinal arterioles in glaucoma. The British Journal Of Ophthalmology 1999; 83: 2859.

118. Papastathopoulos KI, J onas J B. Fluorescein angiographic correlation of focal narrowing of retinal arterioles in glaucoma. The British Journal of Ophthalmology 1998; 82: 48-50.

119. Papastathopoulos KI, J onas JB. Focal narrowing of retinal arterioles in optic nerve atrophy. Ophthalmology 1995; 102: 1706-11.

120. Lee SB, Uhm KB, Hong C. Retinal vessel diameter in normal and primary open-angle glaucoma. Korean Journal Of Ophthalmology: KJO 1998; 12: 519.

121. Lam A, Bunya V, Piltz-Seymour JR. Visual field loss in patients with glaucoma who have asymmetric peripapillary focal arteriolar narrowing. Archives of Ophthalmology (Chicago, IIl: 1960) 2002; 120: 1494-7.

122. Rader J, Feuer WJ, Anderson DR. Peripapillary vasoconstriction in the glaucomas and the anterior ischemic optic neuropathies. American Journal of Ophthalmology 1994; 117: 72-80.

123. Tezel G, Kass MA, Kolker AE, Wax MB. Comparative optic disc analysis in normal pressure glaucoma, primary open-angle glaucoma, and ocular hypertension. Ophthalmology 1996; 103: 2105-13. 
124. de Haseth K, Cheung N, Saw SM, Islam FMA, Mitchell P, Wong TY. Influence of intraocular pressure on retinal vascular caliber measurements in children. American Journal Of Ophthalmology 2007; 143: 1040-2.

125. Lim LS, Saw SM, Cheung N, Mitchell P, Wong TY. Relationship of retinal vascular caliber with optic disc and macular structure. American Journal of Ophthalmology 2009; 148: 368-75.

126. Samarawickrama C, Huynh SC, Wang JJ, Pai A, J oachim N, Burlutsky G, Wong TY, Mitchell P. Relationship between retinal structures and retinal vessel caliber in normal adolescents. Investigative Ophthalmology \& Visual Science 2009; 50: 5619-24.

127. Chang M, Yoo C, Kim S-W, Kim YY. Retinal vessel diameter, retinal nerve fiber layer thickness, and intraocular pressure in korean patients with normaltension glaucoma. American Journal Of Ophthalmology 2011; 151: 100-5.e1.

128. Arend O, Remky A, Plange N, Martin BJ, Harris A. Capillary density and retinal diameter measurements and their impact on altered retinal circulation in glaucoma: a digital fluorescein angiographic study. The British Journal of Ophthalmology 2002; 86: 429-33.

129. Schwartz B. Circulatory defects of the optic disk and retina in ocular hypertension and high pressure open-angle glaucoma. Survey of Ophthalmology 1994; 38 Suppl: S23-S34.

130. J onas J B, Fernández MC, Naumann GO. Parapapillary atrophy and retinal vessel diameter in nonglaucomatous optic nerve damage. Investigative Ophthalmology \& Visual Science 1991; 32: 2942-7.

131. Jonas J B, Xu L. Optic disc morphology in eyes after nonarteritic anterior ischemic optic neuropathy. Investigative Ophthalmology \& Visual Science 1993; 34: 2260-5.

132. Frisén L, Claesson M. Narrowing of the retinal arterioles in descending optic atrophy. A quantitative clinical study. Ophthalmology 1984; 91: 1342-6.

133. Arnold AC. Pathogenesis of nonarteritic anterior ischemic optic neuropathy. Journal Of Neuro-Ophthalmology: The Official Journal Of The North American Neuro-Ophthalmology Society 2003; 23: 157-63. 
134. Talks SJ, Chong NH, Gibson JM, Dodson PM. Fibrinogen, cholesterol and smoking as risk factors for non-arteritic anterior ischaemic optic neuropathy. Eye (London, England) 1995; 9 ( Pt 1): 85-8.

135. Pomeranz HD. Nonarteritic anterior ischemic optic neuropathy and thrombophilia: is there an association? The Journal Of Laboratory And Clinical Medicine 2004; 143: 141-2.

136. Hayreh SS. Anterior ischaemic optic neuropathy. Differentiation of arteritic from non-arteritic type and its management. Eye (London, England) 1990; 4 ( Pt 1): 25-41.

137. Mathews MK. Nonarteritic anterior ischemic optic neuropathy. Current Opinion In Ophthalmology 2005; 16: 341-5.

138. Salomon O, Huna-Baron R, Kurtz S, Steinberg DM, Moisseiev J, Rosenberg N, Yassur I, Vidne O, Zivelin A, Gitel S, Davidson J, Ravid B, Seligsohn U. Analysis of prothrombotic and vascular risk factors in patients with nonarteritic anterior ischemic optic neuropathy. Ophthalmology 1999; 106: 739-42.

139. Giambene B, Sodi A, Sofi F, Marcucci R, Fedi S, Abbate R, Prisco D, Menchini $U$. Evaluation of traditional and emerging cardiovascular risk factors in patients with non-arteritic anterior ischemic optic neuropathy: a case-control study. Graefe's Archive For Clinical And Experimental Ophthalmology = Albrecht Von Graefes Archiv Für Klinische Und Experimentelle Ophthalmologie 2009; 247: 693-7.

140. Lee KE, Klein BEK, Klein R, Meuer SM. Association of retinal vessel caliber to optic disc and cup diameters. Investigative Ophthalmology \& Visual Science 2007; 48: 63-7.

141. Cheung N, Tong L, Tikellis G, Saw SM, Mitchell P, Wang J J, Wong TY. Relationship of retinal vascular caliber with optic disc diameter in children. Investigative Ophthalmology \& Visual Science 2007; 48: 4945-8.

142. Cheung N, Huynh S, Wang JJ, Taylor B, Islam FMA, Saw SM, Wong TY, Mitchell P. Relationships of retinal vessel diameters with optic disc, macular and retinal nerve fiber layer parameters in 6-year-old children. Investigative Ophthalmology \& Visual Science 2008; 49: 2403-8. 
143. Wong TY, Knudtson MD, Klein BEK, Klein R, Hubbard LD. Medication use and retinal vessel diameters. American Journal Of Ophthalmology 2005; 139: 373-5.

144. Howard KP, Klein BEK, Dreyer J O, Danforth LG, Klein R. Cross-sectional associations of medication and supplement use with retinal vascular diameter in the Beaver Dam Eye Study. JAMA Ophthalmology 2014; 132: 23-31.

145. Arend O, Harris A, Arend S, Remky A, Martin BJ. The acute effect of topical beta-adrenoreceptor blocking agents on retinal and optic nerve head circulation. Acta Ophthalmologica Scandinavica 1998; 76: 43-9.

146. Grunwald JE, Delehanty J. Effect of topical carteolol on the normal human retinal circulation. Investigative Ophthalmology \& Visual Science 1992; 33: 1853-6.

147. Wolf $S$, Werner $E$, Schulte K, Reim M. Acute effect of metipranolol on the retinal circulation. The British Journal Of Ophthalmology 1998; 82: 892-6.

148. Grunwald JE. Effect of topical timolol on the human retinal circulation. Investigative Ophthalmology \& Visual Science 1986; 27: 1713-9.

149. Leung M, Grunwald JE. Short-term effects of topical levobunolol on the human retinal circulation. Eye (London, England) 1997; 11 ( Pt 3): 371-6.

150. Grunwald JE. Effect of two weeks of timolol maleate treatment on the normal retinal circulation. Investigative Ophthalmology \& Visual Science 1991; 32: 39-45.

151. Grunwald JE. Effect of timolol maleate on the retinal circulation of human eyes with ocular hypertension. Investigative Ophthalmology \& Visual Science 1990; 31: 521-6.

152. Gupta A, Chen HC, Rassam SM, Kohner EM. Effect of betaxolol on the retinal circulation in eyes with ocular hypertension: a pilot study. Eye (London, England) 1994; 8 ( Pt 6): 668-71.

153. Martin XD, Rabineau PA. Vasoconstrictive effect of topical timolol on human retinal arteries. Graefe's Archive For Clinical And Experimental Ophthalmology = Albrecht Von Graefes Archiv Für Klinische Und Experimentelle Ophthalmologie 1989; 227: 526-30. 
154. Collignon NJ, Collignon-Brach JD. Effect of topical betablockers on human retinal vessels diameters. International Ophthalmology 1997; 21: 199-203.

155. Schwartz B, Takamoto T, Lavin P. Increase of retinal vessel width in ocular hypertensives with timolol therapy. Acta Ophthalmologica Scandinavica Supplement 1995: 41-53.

156. Tilma KK, Bek T. Topical treatment for 1 week with latanoprost but not diclofenac reduces the diameter of dilated retinal arterioles in patients with type 1 diabetes mellitus and mild retinopathy. Acta Ophthalmologica 2012; 90: $750-5$.

157. Kremmer S, Iliadou M, Anastassiou G, Schallenberg M, Vilser W, Steuhl KP, Selbach JM. Influence of latanoprost on retinal microcirculation in glaucoma. The Open Ophthalmology Journal 2014; 8: 60-6.

158. Kóthy P, Holló $G$. Does glaucoma medication influence the diameter of the retinal arteriole in the human eye? (A pilot study using the retinal vessel analyser). Acta Physiologica Hungarica 2001; 88: 281-92.

159. Klein R, Moss SE, Meuer SM, Klein BEK. The 15-year cumulative incidence of retinal vein occlusion: the Beaver Dam Eye Study. Archives Of Ophthalmology (Chicago, III: 1960) 2008; 126: 513-8.

160. Cugati S, Wang JJ, Rochtchina E, Mitchell P. Ten-year incidence of retinal vein occlusion in an older population: the Blue Mountains Eye Study. Archives of Ophthalmology (Chicago, IIl: 1960) 2006; 124: 726-32.

161. Klein R, Klein BE, Moss SE, Meuer SM. The epidemiology of retinal vein occlusion: the Beaver Dam Eye Study. Transactions Of The American Ophthalmological Society 2000; 98: 133-41.

162. Hamid S, Mirza SA, Shokh I. Anatomic pattern of arteriovenous crossings in branch retinal vein occlusion. JPMA The Journal Of The Pakistan Medical Association 2008; 58: 233-6.

163. Zhao J, Sastry SM, Sperduto RD, Chew EY, Remaley NA. Arteriovenous crossing patterns in branch retinal vein occlusion. The Eye Disease CaseControl Study Group. Ophthalmology 1993; 100: 423-8. 
164. Mitchell P, Smith W, Chang A. Prevalence and associations of retinal vein occlusion in Australia. The Blue Mountains Eye Study. Archives Of Ophthalmology (Chicago, III: 1960) 1996; 114: 1243-7.

165. Cheung N, Klein R, Wang JJ, Cotch MF, Islam AFM, Klein BEK, Cushman M, Wong TY. Traditional and novel cardiovascular risk factors for retinal vein occlusion: the multiethnic study of atherosclerosis. Investigative Ophthalmology \& Visual Science 2008; 49: 4297-302.

166. Wong TY, Larsen EKM, Klein R, Mitchell P, Couper DJ, Klein BEK, Hubbard LD, Siscovick DS, Sharrett AR. Cardiovascular risk factors for retinal vein occlusion and arteriolar emboli: the Atherosclerosis Risk in Communities \& Cardiovascular Health studies. Ophthalmology 2005; 112: 540-7.

167. Youm DJ, Ha MM, Chang Y, Song SJ. Retinal vessel caliber and risk factors for branch retinal vein occlusion. Current Eye Research 2012; 37: 334-8.

168. Cugati S, Wang JJ, Knudtson MD, Rochtchina E, Klein R, Klein BEK, Wong TY, Mitchell P. Retinal vein occlusion and vascular mortality: pooled data analysis of 2 population-based cohorts. Ophthalmology 2007; 114: 520-4.

169. Stem MS, Talwar N, Comer GM, Stein JD. A longitudinal analysis of risk factors associated with central retinal vein occlusion. Ophthalmology 2013; 120: $362-70$.

170. Kolar P. Risk factors for central and branch retinal vein occlusion: a metaanalysis of published clinical data. Journal Of Ophthalmology 2014; 2014: 724780-.

171. Rim TH, Kim DW, Han JS, Chung EJ. Retinal vein occlusion and the risk of stroke development: a 9-year nationwide population-based study. Ophthalmology 2015; 122: 1187-94.

172. J anssen MCH, den Heijer M, Cruysberg JRM, Wollersheim H, Bredie SJH. Retinal vein occlusion: a form of venous thrombosis or a complication of atherosclerosis? A meta-analysis of thrombophilic factors. Thrombosis And Haemostasis 2005; 93: 1021-6.

173. Di Capua M, Coppola A, Albisinni R, Tufano A, Guida A, Di Minno MND, Cirillo $F$, Loffredo M, Cerbone AM. Cardiovascular risk factors and outcome in 
patients with retinal vein occlusion. Journal Of Thrombosis And Thrombolysis 2010; 30: 16-22.

174. Risk factors for central retinal vein occlusion. The Eye Disease Case-Control Study Group. Archives Of Ophthalmology (Chicago, III: 1960) 1996; 114: 545-54.

175. Ho J-d, Liou S-W, Lin H-C. Retinal vein occlusion and the risk of stroke development: a five-year follow-up study. American Journal of Ophthalmology 2009; 147: 283-90.e2.

176. Yau JWY, Lee P, Wong TY, Best J, Jenkins A. Retinal vein occlusion: an approach to diagnosis, systemic risk factors and management. Internal Medicine Journal 2008; 38: 904-10.

177. Bertelsen M, Linneberg A, Rosenberg T, Christoffersen N, Vorum H, Gade E, Larsen M. Comorbidity in patients with branch retinal vein occlusion: casecontrol study. BMJ (Clinical Research Ed) 2012; 345: e7885-e.

178. O'Mahoney PRA, Wong DT, Ray JG. Retinal vein occlusion and traditional risk factors for atherosclerosis. Archives Of Ophthalmology (Chicago, III: 1960) 2008; 126: 692-9.

179. Zhou J Q, Xu L, Wang S, Wang YX, You QS, Tu Y, Yang H, J onas JB. The 10year incidence and risk factors of retinal vein occlusion: the Beijing eye study. Ophthalmology 2013; 120: 803-8.

180. Koh V, Cheung CY, Li X, Tian D, Wang JJ, Mitchell P, Cheng C-Y, Wong TY. Retinal Vein Occlusion in a Multi-Ethnic Asian Population: The Singapore Epidemiology of Eye Disease Study. Ophthalmic Epidemiology 2016; 23: 613.

181. Arakawa S, Yasuda M, Nagata M, Ninomiya T, Hirakawa Y, Doi Y, Kiyohara Y, Ishibashi T. Nine-year incidence and risk factors for retinal vein occlusion in a general Japanese population: the Hisayama Study. Investigative Ophthalmology \& Visual Science 2011; 52: 5905-9.

182. Yasuda M, Kiyohara Y, Arakawa S, Hata Y, Yonemoto K, Doi Y, Iida M, Ishibashi T. Prevalence and systemic risk factors for retinal vein occlusion in a general Japanese population: the Hisayama study. Investigative Ophthalmology \& Visual Science 2010; 51: 3205-9. 
183. Hayreh SS, Zimmerman B, McCarthy MJ, Podhajsky P. Systemic diseases associated with various types of retinal vein occlusion. American Journal of Ophthalmology 2001; 131: 61-77.

184. Lim LL, Cheung N, Wang JJ, I slam FMA, Mitchell P, Saw SM, Aung T, Wong TY. Prevalence and risk factors of retinal vein occlusion in an Asian population. The British Journal Of Ophthalmology 2008; 92: 1316-9.

185. Martin SC, Butcher A, Martin N, Farmer J, Dobson PM, Bartlett WA, J ones AF. Cardiovascular risk assessment in patients with retinal vein occlusion. The British Journal Of Ophthalmology 2002; 86: 774-6.

186. Xu L, Liu WW, Wang YX, Yang H, J onas J B. Retinal vein occlusions and mortality: the Beijing Eye Study. American Journal Of Ophthalmology 2007;

144: 972-3.

187. Hu CC, Ho JD, Lin HC. Retinal vein occlusion and the risk of acute myocardial infarction (correction of infraction): a 3-year follow-up study. The British Journal Of Ophthalmology 2009; 93: 717-20.

188. Mansour AM, Walsh JB, Henkind P. Mortality and morbidity in patients with central retinal vein occlusion. Ophthalmologica Journal International D'ophtalmologie International Journal Of Ophthalmology Zeitschrift Für Augenheilkunde 1992; 204: 199-203.

189. Elman MJ, Bhatt AK, Quinlan PM, Enger C. The risk for systemic vascular diseases and mortality in patients with central retinal vein occlusion. Ophthalmology 1990; 97: 1543-8.

190. Laouri M, Chen E, Looman M, Gallagher M. The burden of disease of retinal vein occlusion: review of the literature. Eye (London, England) 2011; 25: 981-8.

191. Corvi F, Querques G, La Spina C, Lattanzio R, Bandello F. DYNAMIC AND STATIC RETINAL VESSEL ANALYSES IN PATIENTS WITH MACULAR EDEMA SECONDARY TO RETINAL VEIN OCCLUSION. Retina (Philadelphia, Pa) 2015; 35: 2052-9.

192. Im JC, Shin JP, Kim IT, Park DH. Recurrence of macular edema in eyes with branch retinal vein occlusion changes the diameter of unaffected retinal vessels. Graefe's Archive For Clinical And Experimental Ophthalmology $=$ 
Albrecht Von Graefes Archiv Fur Klinische Und Experimentelle Ophthalmologie 2015.

193. Sacu S, Pemp B, Weigert G, Matt G, Garhofer G, Pruente C, Schmetterer L, Schmidt-Erfurth $U$. Response of retinal vessels and retrobulbar hemodynamics to intravitreal anti-VEGF treatment in eyes with branch retinal vein occlusion. Investigative Ophthalmology \& Visual Science 2011; 52: 3046-50.

194. Maár N, Luksch A, Graebe A, Ergun E, Wimpissinger B, Tittl M, Vécsei P, Stur $M$, Schmetterer $L$. Effect of laser photocoagulation on the retinal vessel diameter in branch and macular vein occlusion. Archives Of Ophthalmology (Chicago, III: 1960) 2004; 122: 987-91.

195. Park J, Lee S, Son Y. Effects of two different doses of intravitreal bevacizumab on subfoveal choroidal thickness and retinal vessel diameter in branch retinal vein occlusion. International Journal Of Ophthalmology 2016; 9: 999-1005.

196. Arnarsson A, Stefánsson E. Laser treatment and the mechanism of edema reduction in branch retinal vein occlusion. Investigative Ophthalmology \& Visual Science 2000; 41: 877-9.

197. Mitchell P, Wang JJ, Li W, Leeder SR, Smith W. Prevalence of asymptomatic retinal emboli in an Australian urban community. Stroke; A Journal Of Cerebral Circulation 1997; 28: 63-6.

198. Wang J J, Cugati S, Knudtson MD, Rochtchina E, Klein R, Klein BEK, Wong TY, Mitchell P. Retinal arteriolar emboli and long-term mortality: pooled data analysis from two older populations. Stroke; A Journal Of Cerebral Circulation 2006; 37: 1833-6.

199. Hoki SL, Varma R, Lai MY, Azen SP, Klein R. Prevalence and associations of asymptomatic retinal emboli in Latinos: the Los Angeles Latino Eye Study (LALES). American Journal Of Ophthalmology 2008; 145: 143-8.

200. Rudkin AK, Lee AW, Chen CS. Vascular risk factors for central retinal artery occlusion. Eye (London, England) 2010; 24: 678-81.

201. Callizo J, Feltgen N, Pantenburg S, Wolf A, Neubauer AS, Jurklies B, Wachter R, Schmoor C, Schumacher M, Junker B, Pielen A. Cardiovascular Risk Factors 
in Central Retinal Artery Occlusion: Results of a Prospective and Standardized Medical Examination. Ophthalmology 2015; 122: 1881-8.

202. Hayreh SS, Podhajsky PA, Zimmerman MB. Retinal artery occlusion: associated systemic and ophthalmic abnormalities. Ophthalmology 2009; 116: 1928-36.

203. Moss HE. Retinal Vascular Changes are a Marker for Cerebral Vascular Diseases. Current Neurology And Neuroscience Reports 2015; 15: 40-.

204. Klein R, Klein BE, J ensen SC, Moss SE, Meuer SM. Retinal emboli and stroke: the Beaver Dam Eye Study. Archives Of Ophthalmology (Chicago, III: 1960) 1999; 117: 1063-8.

205. Klein R, Klein BEK, Moss SE, Meuer SM. Retinal emboli and cardiovascular disease: the Beaver Dam Eye Study. Archives Of Ophthalmology (Chicago, II: 1960) 2003; 121: 1446-51.

206. Cheung N, Lim L, Wang J J, I slam FMA, Mitchell P, Saw SM, Aung T, Wong TY. Prevalence and risk factors of retinal arteriolar emboli: the Singapore Malay Eye Study. American Journal Of Ophthalmology 2008; 146: 620-4.

207. Wong TY, Klein R. Retinal arteriolar emboli: epidemiology and risk of stroke. Current Opinion In Ophthalmology 2002; 13: 142-6.

208. Cugati S, Wang JJ, Rochtchina E, Mitchell P. Ten-year incidence of retinal emboli in an older population. Stroke; A Journal Of Cerebral Circulation 2006; 37: 908-10.

209. Wong TY, Klein R, Sharrett AR, Manolio TA, Hubbard LD, Marino EK, Kuller L, Burke G, Tracy RP, Polak J F, Gottdiener JS, Siscovick DS. The prevalence and risk factors of retinal microvascular abnormalities in older persons: The Cardiovascular Health Study. Ophthalmology 2003; 110: 658-66.

210. van Hecke MV, Dekker J M, Nijpels G, Stolk RP, Henry RMA, Heine RJ, Bouter LM, Stehouwer CDA, Polak BCP. Are retinal microvascular abnormalities associated with large artery endothelial dysfunction and intima-media thickness? The Hoorn Study. Clinical Science (London, England: 1979) 2006; 110: $597-604$.

211. Klein R, Sharrett AR, Klein BE, Chambless LE, Cooper LS, Hubbard LD, Evans G. Are retinal arteriolar abnormalities related to atherosclerosis?: The 
Atherosclerosis Risk in Communities Study. Arteriosclerosis, Thrombosis, And Vascular Biology 2000; 20: 1644-50.

212. I kram MK, Ong YT, Cheung CY, Wong TY. Retinal vascular caliber measurements: clinical significance, current knowledge and future perspectives. Ophthalmologica Journal International D'ophtalmologie International J ournal Of Ophthalmology Zeitschrift Für Augenheilkunde 2013; 229: $125-36$.

213. Ding J , I kram MK, Cheung CY, Wong TY. Retinal vascular calibre as a predictor of incidence and progression of diabetic retinopathy. Clinical and Experimental Optometry 2012; 95: 290-6.

214. Nguyen TT, Wong TY. Retinal vascular manifestations of metabolic disorders. Trends In Endocrinology And Metabolism: TEM 2006; 17: 262-8.

215. Nguyen TT, Wang JJ, Wong TY. Retinal vascular changes in pre-diabetes and prehypertension: new findings and their research and clinical implications. Diabetes Care 2007; 30: 2708-15.

216. Li L-J, Kamran MI, Wong TY. Retinal vascular imaging in early life: Insights into processes and risk of cardiovascular disease. The Journal Of Physiology 2015.

217. Kee AR, Wong TY, Li L-J. Retinal vascular imaging technology to monitor disease severity and complications in type 1 diabetes mellitus: A systematic review. Microcirculation (New York, NY: 1994) 2016.

218. Nguyen TT, Wong TY. Retinal vascular changes and diabetic retinopathy. Current Diabetes Reports 2009; 9: 277-83.

219. Keel S, Koklanis C, Vukicevic M, Itsiopoulos C, Brazionis L. Diabetes, Diabetic Retinopathy, and Retinal Vascular Alterations: A Systematic Review. AsiaPacific Journal Of Ophthalmology (Philadelphia, Pa) 2014; 3: 164-71.

220. Liew G, Wang JJ. Retinal vascular signs in diabetes and hypertension--review. Arquivos Brasileiros De Endocrinologia E Metabologia 2007; 51: 352-62.

221. Wong TY, Klein R, Sharrett AR, Schmidt MI, Pankow JS, Couper DJ, Klein BEK, Hubbard LD, Duncan BB. Retinal arteriolar narrowing and risk of diabetes mellitus in middle-aged persons. JAMA 2002; 287: 2528-33. 
222. Wong TY, Shankar A, Klein R, Klein BEK, Hubbard LD. Retinal arteriolar narrowing, hypertension, and subsequent risk of diabetes mellitus. Archives Of Internal Medicine 2005; 165: 1060-5.

223. Nguyen TT, Wang JJ, I slam FMA, Mitchell P, Tapp RJ, Zimmet PZ, Simpson R, Shaw J, Wong TY. Retinal arteriolar narrowing predicts incidence of diabetes: the Australian Diabetes, Obesity and Lifestyle (AusDiab) Study. Diabetes 2008; 57: 536-9.

224. Klein R, Klein BEK, Moss SE, Wong TY, Hubbard L, Cruickshanks KJ, Palta M. The relation of retinal vessel caliber to the incidence and progression of diabetic retinopathy: XIX: the Wisconsin Epidemiologic Study of Diabetic Retinopathy. Archives Of Ophthalmology (Chicago, III: 1960) 2004; 122: $76-$ 83.

225. Cheung N, Rogers SL, Donaghue KC, Jenkins AJ, Tikellis G, Wong TY. Retinal arteriolar dilation predicts retinopathy in adolescents with type 1 diabetes. Diabetes Care 2008; 31: 1842-6.

226. Rogers SL, Tikellis G, Cheung N, Tapp R, Shaw J, Zimmet PZ, Mitchell P, Wang JJ, Wong TY. Retinal arteriolar caliber predicts incident retinopathy: the Australian Diabetes, Obesity and Lifestyle (AusDiab) study. Diabetes Care 2008; 31: 761-3.

227. Roy MS, Klein R, Janal MN. Retinal venular diameter as an early indicator of progression to proliferative diabetic retinopathy with and without high-risk characteristics in African Americans with type 1 diabetes mellitus. Archives of Ophthalmology (Chicago, IIl: 1960) 2011; 129: 8-15.

228. Klein R, Myers CE, Lee KE, Gangnon R, Klein BEK. Changes in retinal vessel diameter and incidence and progression of diabetic retinopathy. Archives of Ophthalmology (Chicago, III: 1960) 2012; 130: 749-55.

229. Nguyen TT, Wang JJ, Sharrett AR, Islam FMA, Klein R, Klein BEK, Cotch MF, Wong TY. Relationship of retinal vascular caliber with diabetes and retinopathy: the Multi-Ethnic Study of Atherosclerosis (MESA). Diabetes Care 2008; 31: 544-9. 
230. Kifley A, Wang JJ, Cugati S, Wong TY, Mitchell P. Retinal vascular caliber, diabetes, and retinopathy. American Journal Of Ophthalmology 2007; 143: 1024-6.

231. Klein R, Klein BEK, Moss SE, Wong TY, Hubbard L, Cruickshanks KJ, Palta M. Retinal vascular abnormalities in persons with type 1 diabetes: the Wisconsin Epidemiologic Study of Diabetic Retinopathy: XVIII. Ophthalmology 2003; 110: 2118-25.

232. Klein R, Klein BEK, Moss SE, Wong TY, Sharrett AR. Retinal vascular caliber in persons with type 2 diabetes: the Wisconsin Epidemiological Study of Diabetic Retinopathy: XX. Ophthalmology 2006; 113: 1488-98.

233. Bek T, Hajari J, Jeppesen P. Interaction between flicker-induced vasodilatation and pressure autoregulation in early retinopathy of type 2 diabetes. Graefe's Archive For Clinical And Experimental Ophthalmology = Albrecht Von Graefes Archiv Für Klinische Und Experimentelle Ophthalmologie 2008; 246: 763-9.

234. Mandecka A, Dawczynski J, Blum M, Müller N, Kloos C, Wolf G, Vilser W, Hoyer $\mathrm{H}$, Müller UA. Influence of flickering light on the retinal vessels in diabetic patients. Diabetes Care 2007; 30: 3048-52.

235. Nguyen TT, Kawasaki R, Kreis AJ, Wang J J, Shaw J, Vilser W, Wong TY. Correlation of light-flicker-induced retinal vasodilation and retinal vascular caliber measurements in diabetes. Investigative Ophthalmology \& Visual Science 2009; 50: 5609-13.

236. Moradi A, Sepah YJ, Ibrahim MA, Sophie R, Moazez C, Bittencourt MG, Annam RE, Hanout M, Liu H, Ferraz D, Do DV, Nguyen QD. Association of retinal vessel calibre and visual outcome in eyes with diabetic macular oedema treated with ranibizumab. Eye (London, England) 2014; 28: 1315-20.

237. Soliman W, Vinten M, Sander B, Soliman KAE-N, Yehya S, Rahman MSA, Larsen M. Optical coherence tomography and vessel diameter changes after intravitreal bevacizumab in diabetic macular oedema. Acta Ophthalmologica 2008; 86: 365-71. 
238. Wickremasinghe SS, Rogers SL, Gillies MC, Zhu M, Wong TY. Retinal vascular caliber changes after intravitreal triamcinolone treatment for diabetic macular edema. Investigative Ophthalmology \& Visual Science 2008; 49: 4707-11.

239. Vinten M, Larsen M, Lund-Andersen H, Sander B, La Cour M. Short-term effects of intravitreal triamcinolone on retinal vascular leakage and trunk vessel diameters in diabetic macular oedema. Acta Ophthalmologica Scandinavica 2007; 85: 21-6.

240. Lundberg K, Kawasaki R, Sjølie AK, Wong TY, Grauslund J. Localized changes in retinal vessel caliber after focal/grid laser treatment in patients with diabetic macular edema: a measure of treatment response? Retina (Philadelphia, Pa) 2013; 33: 2089-95.

241. Gottfredsdóttir MS, Stefánsson E, Jónasson F, Gíslason I. Retinal vasoconstriction after laser treatment for diabetic macular edema. American Journal Of Ophthalmology 1993; 115: 64-7.

242. Grauslund J, Hodgson L, Kawasaki R, Green A, Sjølie AK, Wong TY. Retinal vessel calibre and micro- and macrovascular complications in type 1 diabetes. Diabetologia 2009; 52: 2213-7.

243. Wilson CA, Stefánsson E, Klombers L, Hubbard LD, Kaufman SC, Ferris FL, 3rd. Optic disk neovascularization and retinal vessel diameter in diabetic retinopathy. American Journal Of Ophthalmology 1988; 106: 131-4.

244. Grunwald JE, Riva CE, Brucker AJ, Sinclair SH, Petrig BL. Effect of panretinal photocoagulation on retinal blood flow in proliferative diabetic retinopathy. Ophthalmology 1986; 93: 590-5.

245. Berndt-Zipfel C, Michelson G, Dworak M, Mitry M, Löffler A, Pfützner A, Forst T. Vildagliptin in addition to metformin improves retinal blood flow and erythrocyte deformability in patients with type 2 diabetes mellitus - results from an exploratory study. Cardiovascular Diabetology 2013; 12: 59-.

246. Grosso A, Veglio F, Porta M, Grignolo FM, Wong TY. Hypertensive retinopathy revisited: some answers, more questions. The British Journal of Ophthalmology 2005; 89: 1646-54. 
247. Cheung N, Wong TY. Predicting risk of diabetic retinopathy from retinal vessel analysis: personalized medicine in transition. Archives Of Ophthalmology (Chicago, IIl: 1960) 2012; 130: 783-4.

248. McGeechan K, Macaskill P, Irwig L, Liew G, Wong TY. Assessing new biomarkers and predictive models for use in clinical practice: a clinician's guide. Archives Of Internal Medicine 2008; 168: 2304-10.

249. Wong TY. Retinal vessel diameter as a clinical predictor of diabetic retinopathy progression: time to take out the measuring tape. Archives of Ophthalmology (Chicago, IIl: 1960) 2011; 129: 95-6.

250. Yanagi M, Misumi M, Kawasaki R, Takahashi I, Itakura K, Fujiwara S, Akahoshi M, Neriishi K, Wong TY, Kiuchi Y. Is the association between smoking and the retinal venular diameter reversible following smoking cessation? Investigative Ophthalmology \& Visual Science 2014; 55: 405-11.

251. Serre K, Sasongko MB. Modifiable lifestyle and environmental risk factors affecting the retinal microcirculation. Microcirculation (New York, NY: 1994) 2012; 19: 29-36.

252. Hanssen H, Nickel T, Drexel V, Hertel G, Emslander I, Sisic Z, Lorang D, Schuster T, Kotliar KE, Pressler A, Schmidt-Trucksäss A, Weis M, Halle M. Exercise-induced alterations of retinal vessel diameters and cardiovascular risk reduction in obesity. Atherosclerosis 2011; 216: 433-9.

253. Thom S, Stettler C, Stanton A, Witt N, Tapp R, Chaturvedi N, Allemann S, Mayet J, Sever P, Poulter N, O'Brien E, Hughes A. Differential effects of antihypertensive treatment on the retinal microcirculation: an angloscandinavian cardiac outcomes trial substudy. Hypertension 2009; 54: 405-8.

254. Hughes AD, Stanton AV, Jabbar AS, Chapman N, Martinez-Perez ME, McG Thom SA. Effect of antihypertensive treatment on retinal microvascular changes in hypertension. Journal Of Hypertension 2008; 26: 1703-7.

255. Dahlöf B, Stenkula S, Hansson L. Hypertensive retinal vascular changes: relationship to left ventricular hypertrophy and arteriolar changes before and after treatment. Blood Pressure 1992; 1: 35-44. 
256. Strachan MWJ, McKnight J A. I mages in clinical medicine. I mprovement in hypertensive retinopathy after treatment of hypertension. The New England Journal Of Medicine 2005; 352: e17-e.

257. Sasaki M, Gan WL, Kawasaki R, Hodgson L, Lee KY, Wong TY, Lamoureux E, Robman L, Guymer R. Effect of simvastatin on retinal vascular caliber: the Age-Related Maculopathy Statin Study. Acta Ophthalmologica 2013; 91: e418-e9.

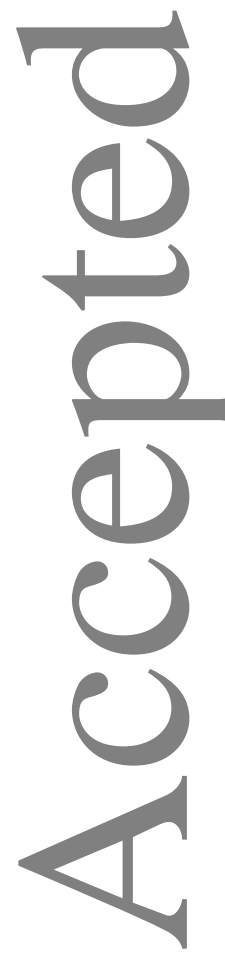



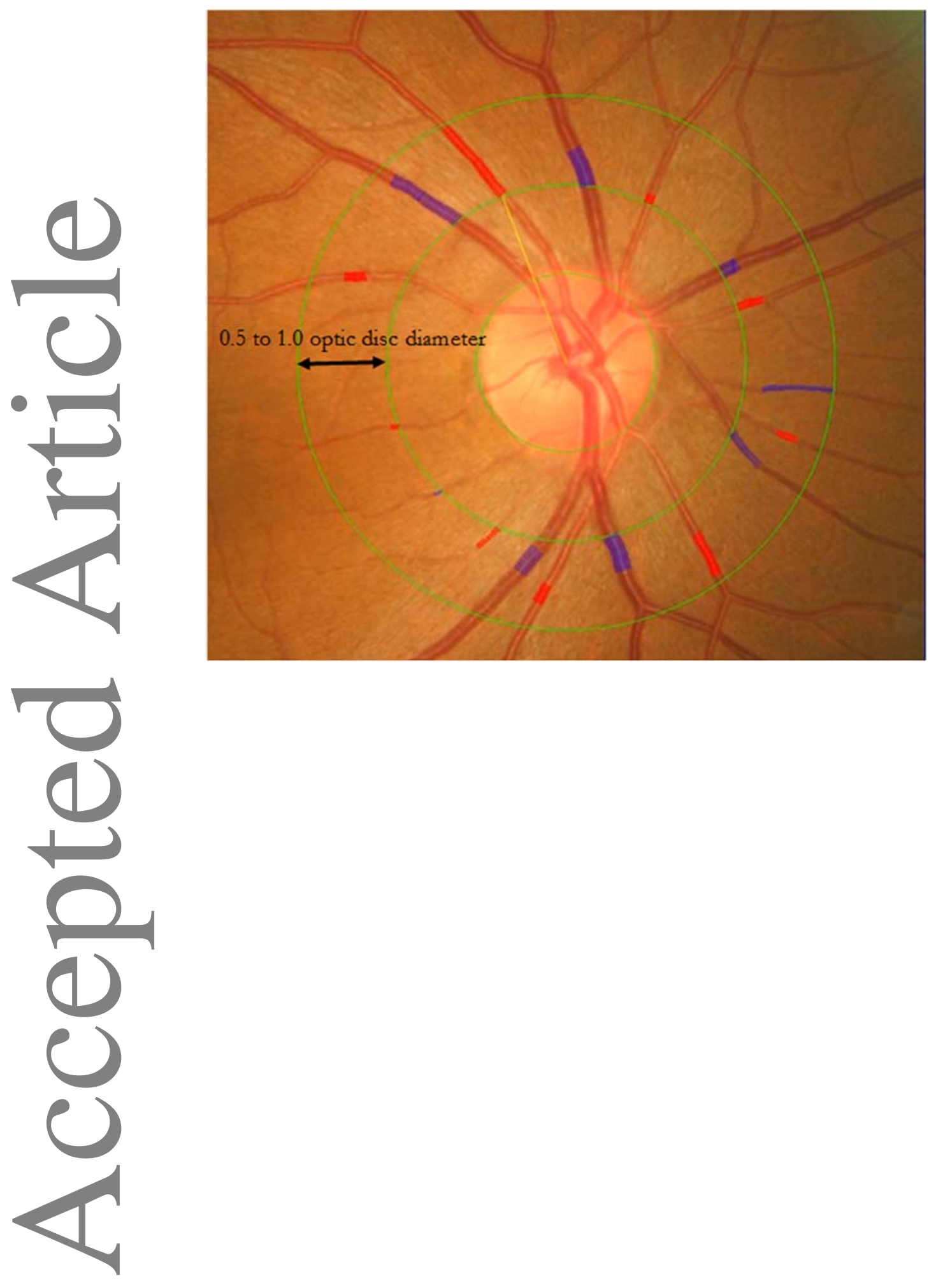
